\title{
Proje Karmaşıklığının Ölçümlenmesine Yönelik Bir Model Önerisi
}

\author{
A Model Suggestion for Measuring Project Complexity \\ Ezgi GÜRELER GÖNEN ${ }^{1}$ (D), Ayberk SOYER ${ }^{1}$ \\ ${ }^{1}$ İstanbul Teknik Üniversitesi, Endüstri Mühendisliği Bölümü, 34357, İstanbul, Türkiye
}

Öz

Proje yönetimi; entegrasyon, kapsam, zaman, maliyet, kalite, insan kaynağı, iletişim, tedarik ve risk yönetimi konularına odaklanmaktadır. Proje karmaşıklığı bu başlıkların hiçbiri altında değerlendirilemeyen; ancak projelerin başarılı bir şekilde yönetilmesi ve sonuçlanmasında önemli bir etkiye sahip olan farklı bir konudur. Dolayısıyla proje karmaşıklı̆ının, farklı birçok açıdan değerlendirilmesi gereken bir proje yönetim boyutu olarak düşünülmesi ve proje yönetim sürecinde mutlaka dikkate alınmasi gerekmektedir.

Proje karmaşıklığının yönetilebilir hale gelmesi için projeleri yönetirken karmaşıklık yaratacak her bir faktörün ve etkilerinin net olarak tanımlanması ve ölçümlenmesi gerekmektedir. Tanımlanan faktörlerin etkin ve kolay bir şekilde ölçümlenebilmesi, ancak faktörlerin sistematik olarak bir araya getirilmesiyle mümkün olmaktadır. Ayrıca bütünsel açıdan bakıldığında, bu yaklaşım, ilk bakışta tespit edilemeyen faktörlerin de ortaya çıkarılmasını mümkün hale getirmektedir. Bu sebeple proje karmaşıklığının ölçümlenmesine yönelik oluşturulmuş çerçeveler ve bu çerçevelerde yer alan boyutlar, proje karmaşıklığının tanımlanması ve ölçümlenmesi için kritik öneme sahiptir.

$\mathrm{Bu}$ çalışma, projelerde karmaşıklığın ölçümlenmesine yönelik yeni bir model geliştirmek ve proje yönetim süreçlerine katk1 sağlamak amacıyla gerçekleştirilmiştir. Çalışma kapsamında literatürde proje karmaşıklığına yönelik yapılan tanımlar, karmaşıklığı etkileyen faktörler ve bu faktörlere yönelik yapılan sınıflandırmalar, oluşturulan boyutlar ve karmaşıklık ölçümm araçları araştırılmış ve proje karmaşıklığının ölçümlenmesine yönelik yeni bir model önerisi sunulmuştur. Sunulan model, dijital bankacılık projelerinde karmaşıklığın ölçümlenmesine yönelik bir uygulamada kullanılmıştır. Uygulama ile ele alınan projelerin karmaşıklaşmasına en çok katk1 sağlayan temel faktörler ve alt faktörler belirlenmiş ve alternatif projelerin karmaşıklık seviyeleri kıyaslanmıştır. Projeyi yönetmeyi karmaşık hale getiren unsurları tanımlamak ve proje yönetimi için ortak bir anlayış sağlamak, hem akademik çalışmalara hem de proje uygulayıcılarına bu unsurların nasıl yönetileceği konusunda yardımcı olacaktır.

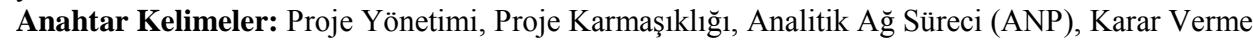

\begin{abstract}
Project management focuses on integration, scope, time, cost, quality, human resources, communication, procurement and risk management issues. Project complexity is a different issue that cannot be evaluated under any of these topics, and has a significant impact on the successful management and conclusion of projects. Therefore, it should be considered in the project management process and should be evaluated from different perspectives.

In order to make the project complexity manageable, each factor that create complexity together with their effects should be defined and measured. The effective and easy measurement of the identified factors is only possible by systematically combining them. Moreover, from a holistic perspective, this approach makes it possible to reveal the factors that cannot be detected at first glance. For this reason, the frameworks created for measuring the project complexity and the dimensions included in these frameworks are obviously critical.

This study was carried out to develop a new model for measuring project complexity. Within the scope of this study, the definitions proposed for project complexity, the factors influencing it, the dimensions created to measure it, and the complexity measurement tools were researched, and a new model was developed for measuring project complexity and used in an application for measuring complexity in digital banking projects. The main factors and sub-factors contributing most to the complexity of the relevant projects were determined, and the complexity levels of these projects were compared. Identifying the factors that complicate the project management process will help both academic studies and project practitioners in how to manage these factors.
\end{abstract}

Keywords: Project Management, Project Complexity, Analytical Network Process (ANP), Decision Making 


\section{GİRIŞ}

Proje, bir probleme çözüm bulmak ya da bir firsatı değerlendirmek amacıyla değişim yaratmayı hedefleyen, belirli bir zaman hedefi ve belirli bir bütçe dâhilinde gerçekleştirilen çalışmadır. Proje yönetimi, projenin gerekliliklerinin yerine getirilmesi için projenin aktivitelerine çeşitli bilgi, yetkinlik, araç ve tekniklerin uygulanmasını gerektirir ve başlangıç, planlama, uygulama, kontrol ve kapanış süreçlerinin başarılı bir şekilde gerçekleşmesini sağlar. Proje Yönetimi Bilgi Birikimi Kılavuzuna (PMBOK) göre, proje yönetimi dokuz farklı sürecin yönetilmesine odaklanmaktadır: (i) entegrasyon yönetimi, (ii) kapsam yönetimi, (iii) zaman yönetimi, (iv) maliyet yönetimi, (v) kalite yönetimi, (vi) insan kaynăğ yönetimi, (vii) iletişim yönetimi, (viii) risk yönetimi ve (ix) tedarik yönetimi [1].

Literatürde proje yönetimi ile ilgili hemen hemen bütün kaynaklarda, bu temel süreçlerin yanı sıra, karmaşıklık, zorluk, belirsizlik, vb. farkl k kavramlar da yer almaktadır. Bahsedilen bu kavramlar genellikle birbirleri ile karıştırılmakta ve birbirleri yerine kullanılmaktadır; ancak doğru bir yönetim için bu kavramların birbirinden ayrıştırılması gerekmektedir. Karmaşıklık, birden fazla farklı öge ve bunların ilişkilerinden kaynaklanan bir olgudur. Belirsizlik, birçok sonucun gerçekleşebileceği durumlarda sahip olunan limitli bilgi sebebiyle sonucun öngörülememesi durumudur. Risk ise, bir kişi veya kurumun hedeflerini gerçekleştirmesini engelleyebilecek herhangi bir durumun ortaya çıkma olasillğı ve ortaya çıktığ durumda yaratacağı etkidir. Proje risk yönetimi, bilinmeyen olayların veya bilinen olayların bilinmeyen sonuçlarının, proje üzerindeki etkilerini ölçmeye çalışır. Proje karmaşıklığı ise projenin bilinen karakteristiklerine ve bunların birbirlerini nasıl etkilediklerine odaklanır. Proje karmaşıklığı ile ilgili doğru yönetim stratejilerinin kurulabilmesi, karmaşıklık kavramı ile risk ve belirsizlik kavramlarının doğru ayrıştırılması ile doğrudan ilişkilidir [2]. Proje zorluğu ise proje takımının uzmanlığına dayalı bir kavramdır. Wood ve Ashton (2015)'ı çalışmasında karmaşık kelimesi, anlaşılması, analiz etmesi ya da başa çıması zor olmaktan ziyade, birkaç kısımdan oluşan şey olarak ifade edilmekte ve zorluk ve karmaşıklık kavramlarının birbirinden farklı oldukları vurgulanmaktadır [3]. Proje karmaşıklığı, proje zorluğunun temelidir; projeyi tamamlamayı zorlaştırır ve proje risklerini kontrol altında tutmak için özel bir çaba gerektirir [4]. Risk, belirsizlik ya da zorluk kavramlarından farklı bir kavram olması sebebiyle karmaşıklığın, projeleri etkileyen farklı bir faktör olarak değerlendirilmesi gerekmektedir.

Karmaşıklıkta, belirsizlik ve dinamizm hâkimdir [5, 6]. $\mathrm{Ne}$ olacağı kestirilemeyen durumlar bir araya geldiğinde karmaşık bir hal alması kaçınılmazdır. Dinamizm, davranışların canlı ve hareketli olması anlamına gelmektedir ki sürekli değişen, hareket halinde olan bir sistemde akışı yakalamak, sistemin büyüklüğü gibi etkenler de göz önüne alındığında oldukça zordur.

Proje karmaşıklığının belirlenmesi ve ölçümlenmesi konusunda yapılan çalışmalar, karmaşıklık ile ilgili konuları adresleyebilme hususunda insanların kabiliyetlerini artıracak modeller ve yöntemler önermekte ve proje yönetiminde rol alan bireylerin zaman, maliyet ve kapsam ile ilgili konulardaki rollerine dikkat çekmektedir. Proje karmaşıklığının tanımlanması ve büyüklüğünün belirlenmesi, projenin başarılı bir şekilde tamamlanması için engel teşkil edebilecek önemli bir faktöre yönelik önlemler alınmasına firsat sunar. Özellikle erken aşamalardan itibaren yapılan karmaşıklık ölçümleri; projelerde uygun stratejiler ile ilerlenmesini, en elverişli yöntem ve araçların tercih edilmesini, en doğru tecrübe ve yetkinlikteki çalş̧anlarla süreçlerin yürütülmesini veya ihtiyaçlar doğrultusunda çalışanları eğitimlerle destekleyerek gelişimlerine katkı sağlanması yoluyla, projelerde başarıya ulaşılmasında etkin rol oynar.

Baccarini (1996) yaptığı çalışmada gözlemlerine göre proje yöneticilerinin, proje yönetimi ile ilgili konular hakkında tartışırken genellikle projelerini "basit" ya da "karmaşık" şeklinde tanımladıklarını ifade etmiş ve bu gözlemden hareketle, karmaşıklık konusunun, proje yönetiminde bir fark yarattı̆̆ çııarımında bulunmuştur [5]. Karmaşı1k projeler, basit projelere göre, daha üst seviye bir yönetime ihtiyaç duyarlar. Bu sebeple sıradan projeler için geliştirilmiş geleneksel proje yönetim teknikleri karmaşık projeler için yetersiz kalacaktır. Tüm bu söylemler sonucu proje yönetiminin karmaşıklık yönetimi ile ilişkili olduğu sonucuna varılabilir. Baccarini (1996) proje yönetimi sürecinde karmaşıklık yönetiminin önemli olduğunu şu gerekçelerle açıklamıştır: Proje karmaşıklığı;

- planlama, koordinasyon ve kontrol gerekliliklerinin belirlenmesinde etkilidir.

- büyük projelerde hedeflerin açıkça görülmesini engeller.

- uygun proje organizasyon şeklinin seçilmesi için önemli bir ölçüttür.

- proje girdilerinin belirlenmesinde rol oynar.

- uygun proje tedarik anlaşmalarının seçiminde bir ölçüt olarak kabul edilebilir.

- projenin zaman, maliyet ve kalite hedeflerine etki eder (proje karmaşıklığı arttıkça proje için gerekli zaman ve maliyet artacaktır) [5].

Her proje kendine özgüdür; çünkü hedef, kaynak ve çevre parametrelerinden en az bir tanesi mutlaka farkl1lık gösterir. Bu durum, proje yönetimini daha da karmaşık hale getirmektedir. Proje karmaşıklığı gidererek artmakta ve modern proje yönetimini desteklemek için daha iyi anlaşılmaya ve ölçümlenmeye ihtiyaç duymaktadır [7]. Proje karmaşıklığının doğru bir şekilde belirlenmesi, 
ölçümlenmesi ve yönetilmesi, başarılı bir proje yönetimine büyük oranda katkı sağlayacaktır.

\subsection{Proje Karmaşıklığı Kavramının Tanımlanması} Literatürde sıkça kullanılan tanımlar karmaşıklığı en basit haliyle "etkileşim halinde bulunan çok sayıda ögeye sahip olma karakteristiği”" şeklinde açıklamaktadır. Ancak araştırma konusu olarak ele alındığında karmaşıklık kavramı için yapılan bu tanım yetersiz kalmaktadır. Birçok bilim insanı karmaşıklığ kendi alanlarına göre farklı şekillerde tanımlamış ve mutabık kalınan bir tanım henüz ortaya çıkmamıştır.

Standart bir tanım olmadığı sürece, karmaşıklık, sonuçları tahmin edilemeyen, detayları tam olarak anlaşılamayan ya da bunlar dışında normal dışı olarak algılanan sayısız durumdan birini içeren projeler için, farklı şekillerde algılanabilir. Proje uzmanları ve takımları bir projenin karmaşık olup olmadığını sezgileri ile hissedebilirler. Ancak karmaşıklı̆̆ın sebepleri çok çeşitli olabilir ve objektif ya da sübjektif farklı birçok kaynağa bağlı olabilir. Ek olarak, karmaşıklık algısı birçok proje faktörü ile şiddetlenebilir ve aktif olarak yönetilemediği durumlarda proje çıktılarında negatif etkilere sebep olabilir.
Cicmil ve diğ. (2009) proje karmaşıklığını "planlama ve kontrol uygulamalarının kararlaştırılmasına yardımcı olan amaç ve hedeflerin tanımlanmasını engelleyen ya da projenin zaman, maliyet ve kalitesini etkileyen bir faktör" olarak [8]; Vidal ve diğ. (2011) "proje sistemi ile ilgili kabul edilebilir bütünlükte bir bilgi verilmiş olsa dahi, projenin tüm hareketlerinin anlaşılmasını, öngörülmesini ve kontrol altında tutulmasını zorlaştıran bir özellik" olarak tanımlamış [7] ve karmaşıklığı değerlendirmenin öneminin altını çizmişlerdir.

Lu ve diğ. (2015) karmaşıklığın tanımlaması zor olan, ancak ölçülmesi daha da zor olan bir kavram olduğunu ifade etmiştir [2]. Karmaşıklığı tanımlanması zor bir kavram yapan en temel unsur, aslında karmaşıklığı oluşturan kavramların da açıklanmasının, tahmin edilmesinin ve ölçümlenmesinin zor olmasıdır. Dao ve diğ. (2016b) proje karmaşıklığının, değişkenler ve ara yüzler arasındaki ilişkilerin derecesi ve bu ilişkilerin öngörülebilirlik ve işlevsellikleri üzerinde önemli etkisi olduğunu ifade etmiştir [4]. Proje karmaşıklığı ile ilgili literatürde yer alan temel çalışmalarda yer alan tanımlar Tablo 1'de özetlenmiştir.

Tablo 1. Literatürde yer alan proje karmaşıklığı tanımları

\begin{tabular}{|c|c|}
\hline Kaynak & Tanım \\
\hline Baccarini (1996) [5] & Etkileşim halinde bulunan çok sayıda ögeye sahip olma karakteristiği \\
\hline Gidado (1996) [9] & $\begin{array}{l}\text { Birleştirilmesi gereken çok sayıda farklı sisteme sahip olmak ya da elemanlar arası } \\
\text { çok sayıda ara yüz bulundurmak }\end{array}$ \\
\hline Williams (1999) [10] & İlişkili birçok kısımdan oluşan bir yapı ve bu yapıyı etkileyen belirsizlikler \\
\hline Lucas (2006) [11] & Birbirleri ile birçok farklı şekilde etkileşim halinde olan elemanlardan oluşan bir bütün \\
\hline $\begin{array}{ll}\text { Brockmann } & \text { ve } \\
\text { Grimscheid (2007) [12] }\end{array}$ & Karar verme noktalarındaki bolluğun, ilişkililiğin ve sıralı etkilerin derecesi \\
\hline $\begin{array}{l}\text { Cicmil ve diğ. (2009) } \\
\text { [8] }\end{array}$ & $\begin{array}{l}\text { Planlama ve kontrol uygulamalarının kararlaştırılmasına yardımcı olan, amaç ve } \\
\text { hedeflerin tanımlanmasını engelleyen ya da projenin zaman, maliyet ve kalitesini } \\
\text { etkileyen bir faktör }\end{array}$ \\
\hline $\begin{array}{l}\text { Bosch-Rekveldt ve diğ. } \\
\text { (2011) [13] }\end{array}$ & Projelerdeki yapısal ve dinamik elemanlar ve bunlar arasındaki ilişkiler \\
\hline Vidal ve diğ. (2011) [7] & $\begin{array}{l}\text { Proje sistemi ile ilgili kabul edilebilir bir bütünlükte bilgi verilmiş olsa dahi projenin } \\
\text { tüm hareketlerinin anlaşılmasını, öngörülmesini ve kontrol altında tutulmasını } \\
\text { zorlaştıran bir özellik }\end{array}$ \\
\hline $\begin{array}{l}\text { Xia ve Chan (2012) } \\
\text { [14] }\end{array}$ & Projenin birbirine bağlı kısımlarından kaynaklanan doğal karakteristikleri \\
\hline $\begin{array}{l}\text { Wood ve Ashton (2015) } \\
\text { [3] }\end{array}$ & $\begin{array}{l}\text { Proje çıktılarını başarmak için alınan standart cevapları/aksiyonları etkileyen faktör } \\
\text { veya faktörlerin birleşimi }\end{array}$ \\
\hline Lu ve diğ. (2015) [2] & $\begin{array}{l}\text { Birçok çeşitli ilişkili parçalardan oluşan ve 'dinamik', 'aniden beliren', vb. özellikleri } \\
\text { barındıran faktör }\end{array}$ \\
\hline $\begin{array}{l}\text { Remington ve Pollack } \\
(2016)[15]\end{array}$ & $\begin{array}{l}\text { Projeyi yönetmeyi veya proje çıktılarını tahmin etmeyi zorlaştıran bir proje } \\
\text { karakteristiği }\end{array}$ \\
\hline Dao ve diğ. (2016b) [4] & $\begin{array}{l}\text { Değişkenler ve ara yüzler arasındaki ilişkilerin derecesi ve bu ilişkilerin } \\
\text { öngörülebilirlik ve işlevsellik üzerindeki önemli etkisi }\end{array}$ \\
\hline Dao ve diğ. (2017) [16] & $\begin{array}{l}\text { Proje elemanlarının tanımlanma derecesi, proje elemanları arasındaki ilişkiler ve proje } \\
\text { kararları üzerindeki önemli etkiler }\end{array}$ \\
\hline
\end{tabular}

Geraldi ve diğ. (2011)'ne göre karmaşık denen şey, doğası gereği zamanla değişmektedir ve proje yaşam döngüsü boyunca görece olarak uzun dönemlerde değişmesi beklenen bir durumdur [6]. Karmaşık bir sistemdeki birçok bağımsız eleman sürekli etkileşim halindedirler ve kendiliğinden (yeniden) organize 
olarak, zamanla yapıların karmaşıklığını artırmaktadırlar [16]. Baccarini (1996)'nin yaptığı "etkileşim halinde bulunan çok sayıda ögeye sahip olma karakteristiği” tanımı aslında karmaşıklık kavramı ile ilgili iki temel noktayı vurgulamaktadır: (i) çeşitli ögeler ve (ii) bunların etkileşimi [5]. Baccarini (1996) yaptığı çalışmada karmaşıklık ile ilgili bu iki temel noktaya değinmiş ve bunları 'ilişkili çeşitli birçok kısım içermek' ve 'karışık, girift, anlaşılması güç' olmak şeklinde ifade etmiştir [5].

Gidado (1996) inşaat sektöründe yaptığı çalışmada sektör uzmanları ile yaptığı görüşmelerde karmaşıklığ "birleştirilmesi gereken çok sayıda farklı sisteme sahip olmak ya da elemanlar arası çok sayıda ara yüz bulundurmak" şeklinde tanımlamış ve proje karmaşıklığının iki yönü olduğunu ileri sürmüştür: (i) iş ile ilgili çok sayıdaki kısmın, iş akışı şekline gelmesi için nasıl bir araya getirileceğinin planlanmasını ifade eden yönetsel taraf ve (ii) iş parçalarının uygulanmasının zorluğu ya da teknik anlaşılmazlıkları ifade eden operasyonel ve teknolojik taraf [9].

Proje karmaşıklığı ile ilgili farklı alanlarda farklı tanımlar yapılmış olsa da proje yönetimi bakış açısıyla yapılan tüm değerlendirmeler dikkate alındığında proje karmaşıklığ 1 , "birbirleri ile ilişki derecesi yüksek olan çok sayıda öge barındırmak" şeklinde tanımlanabilir. Proje karmaşıklığı; farklı birçok boyut açısından ayrı ayrı değerlendirilmesi gereken, her bir boyut için faktörlerin ve etkilerinin net olarak tanımlanmasının kritik olduğu bir kavram olarak değerlendirilmelidir.

\subsection{Proje Karmaşıklığı Kavramının Ölçümlenmesi}

Proje karmaşıklığının etkin bir şekilde yönetilmesi için proje karmaşıklığının tanımlanması önemli bir adımdır. Karmaşıklık daha önce bahsedildiği gibi birçok etkenden meydana gelen soyut bir kavramdır. Dolayısıyla, belirli bir proje için karmaşıklık tanımı yapılırken ilk adım olarak karmaşıklığı oluşturan etkenlerin, bileşenlerin ve özelliklerin ortaya konması gerekmektedir. $\mathrm{Bu}$ kavramların ölçümlenmesi genellikle mümkün değildir. Kavramların ölçümlenmesini mümkün hale getirmek, ancak bu kavramlarla ilişkilendirilebilecek göstergelerin belirlenmesi ile mümkün olacaktır. Belirlenen bu göstergeler proje karmaşıklığının ölçümlenmesi ve değerlendirilmesini sağlayacaktır.

Projelerde karmaşıklığın tanımlanması; karmaşıklıkla ilgili en önemli faktörlerin belirlenmesi ve bu faktörleri yansıtabilecek göstergelerin oluşturulması süreçlerini içermelidir. Wood ve Ashton (2015)'a göre, karmaşıklıkla ilgili herhangi bir ölçek seçilmeden önce projeyi karmaşıklaştıran faktörlerin tanımlanması esastır [3]. Dao ve diğ. (2017) proje karmaşıklığının keşfedilmesi ve değerlendirilmesinin, ancak iki spesifik hedef ile gerçekleşebileceğini belirtmiştir: (i) karmaşıklığın ve bileşenlerinin tanımlanması ve (ii) proje karmaşıklığının ölçüsü olan karmaşıklık göstergelerinin öneminin tanımlanması ve test edilmesi [16].

Farklı türdeki karmaşıklıklar, farklı yönetim metotlarına ihtiyaç duyar [15]. Farklı türdeki karmaşıklıkların tanımlanması, projeyi yönetmek için en uygun araç ve yöntemlerin belirlenmesine olanak sağlayacağından başarılı bir proje yönetimi için oldukça önemlidir.

Qureshi ve Kang (2015) proje karmaşıklığının çeşitli formlarda olduğunu ve sosyal, teknolojik, çevresel ve organizasyonel bakış açılarıyla anlaşılabileceğini belirtmiştir [17]. Maylor ve diğ. (2008) yaptıkları çalışmada proje karmaşıklığını yönetsel karmaşıklık olarak ele almış ve elemanlarını misyon, organizasyon, çıktılar, paydaşlar ve takım olarak gruplandırmıştır [18]. Remington ve Pollack (2016) proje karmaşıklığını etkileyen faktörleri dört başlık altında toplamıştır: (i) yapısal karmaşıklık, (ii) teknik karmaşıklık, (iii) yönsel karmaşıklık ve (iv) geçici karmaşıklık [15]. Brockmann ve Girmscheid (2007)'da karmaşıklığ temelde dört kategoride incelemiştir: (i) görev karmaşıklığı, (ii) sosyal karmaşıklık, (iii) kültürel karmaşıklık ve (iv) genel karmaşıklık [12]. Dao ve diğ. (2016a)'ne göre projenin bileşenlerinin sayısı, her bir bileşenin aktiflik derecesi, bileşenler arasındaki etkileşimin derecesi (veya projedeki ara yüzler) ve proje ile proje dışındaki varlıkların etkileşimi, proje karmaşıklığını yaratan başlica etkenlerdir [19]. Vidal ve Marle (2008) yaptıkları çalışmada proje karmaşıklığının değişkenlerini dört boyut altında sınıflandırmışlardır: (i) proje ölçeği, (ii) proje bileşenlerinin ayrıştırılması, (iii) proje bileşenleri arasındaki etkileşim ve (iv) dışsal/çevresel faktörler ile etkileşim [20]. Lu ve diğ. (2015) proje karmaşıklığının görev ve organizasyon olmak üzere iki boyutu olduğunu belirtmiştir [2]. Brockmann ve Grimscheid (2007) karmaşıklığın boyutlarını ayrıştırarak, karmaşıklık ile başa çıkabilecek stratejilerin seçilmesine katkı sağlamak ve proje karmaşıklığını azaltmak amacıyla yaptıkları çalışmada, proje karmaşıklığını genel karmaşıklık, sosyal karmaşıklık, kültürel karmaşıklık ve görev karmaşıklığı olmak üzere dört temel boyutta gruplandırmıştır [12]. Bosch-Rekveldt ve diğ. (2011) ise proje karmaşıklığı ile ilgili, belirledikleri 50 faktörü içeren ve bu faktörleri teknik, organizasyonel ve çevresel olmak üzere üç ailede toplandıkları TeknikOrganizasyonel-Çevresel Çerçeveyi (TOE: TechnicalOrganizational-Environmental geliştirmişlerdir [13].

Baccarini (1996) projenin karmaşıklığını etkileyen faktörlerin organizasyonel karmaşıklık ve teknolojik karmaşıklık olmak üzere iki temel boyutta gruplanabileceğini belirtmiştir [5]. Proje karmaşıklığının işlevselleştirilmesinin, ancak onu oluşturan parçaların farklılaştırma ve bağımlılık açılarından ele alınmasıyla mümkün olduğunu belirten Baccarini (1996), belirlediği iki temel boyutu, 
farklılaştırma ve bağımlılık açısından ayrı ayrı değerlendirmiştir [5].

$\mathrm{Lu} \quad$ ve diğ. (2015) proje karmaşıklığının ölçümlenmesine yönelik yaptıkları çalışmada görev ve organizasyon boyutlarını içeren Görev ve Organizasyon Çerçevesini (TO: Task and Organization Framework) önermiş, karmaşıklık boyutlarını organizasyonel ve görevler şeklinde düşünmekten çok, görevler arası ilişkiler ve organizasyondaki kişiler arası ilişkiler olarak dikkate almış ve her iki boyutu hem teker teker hem de ilişkiler bakımından değerlendirmiştir [2].

Zhu ve Mostafavi (2017) sistemlerde iki tip karmaşıklık olduğunu savunmuştur: Detay karmaşıklık ve dinamik karmaşıklık [21]. Detay karmaşıklık değişkenlerin çok sayıda olmasından kaynaklanan, dinamik karmaşıklık ise sebep-sonuç ilişkilerinin net olmadığı ve zamanla değiştiği durumlarda bileşenler arasındaki ilişkilerden kaynaklanan karmaşıklıktır. Detay karmaşıklık proje sistemi ile alakalı iken, dinamik karmaşıklık sistemdeki elemanlara dayalı operasyonel süreçlerle alakalıdır.

Vidal ve diğ. (2011) proje karmaşıklığının ölçümlenmesi için literatürdeki çalışmaları inceleyerek, 70 adet gösterge listelemiş ve belirledikleri karmaşıklık faktörlerini hem Baccarini (1996)'nin [5] geleneksel çerçevesine göre organizasyonel ve teknolojik olarak gruplandırmış, hem de literatürde yaygın olarak kullanılan büyüklük, çeşitlilik, bağımlılık ve içerik bağımlılık faktörlerine göre gruplandırmışlardır [7].

GAPPS (Global Alliance for Project Performance Standarts: Proje Performans Standartları Uluslararası İttifakı) 2007 yılında bir proje yöneticisi standardı olarak CIFTER (Crawford-Ishikura Factor Table for Evaluating Roles: Görevlerin Değerlendirilmesi için Crawford-Ishikura Faktör Tablosu) adı verilen yedi faktörlü bir proje yönetimi karmaşıklık ölçüm modeli geliştirmiştir: (i) proje içeriğinin durağanlığı, (ii) proje gerçekleşirken dâhil olan farklı disiplin, yöntem veya yaklaşımların sayısı, (iii) proje gerçekleşirken yasal, sosyal veya çevresel etkilerin büyüklüğü, (iv) proje paydaşları için beklenen pozitif ya da negatif finansal etki, (v) organizasyonun kendisi ya da dâhil olan diğer organizasyonlar için projenin stratejik önemi, (vi) proje ürününün özellikleri konusunda paydaşların uyumu ve (vii) proje ve diğer organizasyonel varlıklar arasındaki ara yüzlerin sayısı ve çeşitliliği [22]. CIFTER, projeleri, yönetim karmaşıklıklarına göre kategorilere ayırmaya dayanmakta ve yönetilen projelerin karmaşıklığ 1 doğrultusunda proje yöneticilerinin görevlerini farklılaştırmak için kullanılmaktadır. Yöntemde belirlenmiş faktörler, proje yönetimi karmaşıklığııın sebeplerini tanımlamaktadır.

Dao ve diğ. (2016a), proje uygulayıcılarının, projelerin karmaşıklığını etkin bir şekilde tanımlamaları, değerlendirmeleri ve yönetmeleri için bütünleşik bir karmaşıklık çalışmasına ihtiyaç olduğunu; ancak literatürde karmaşıklığı ölçen ciddi sayıda çalışma olmasına rağmen, proje karmaşıklığını tanımlayan, boyutlarını belirleyen ve karmaşıklık seviyesini ölçecek bir metodoloji sunan bütünleşik bir çalışma olmadığını belirtmişlerdir [19]. Geliştirdikleri Proje Karmaşıklığı Değerlendirme ve Yönetme Arac1 (PCAM: Project Complexity Assessment and Management) ile proje takımlarının, proje karmaşıklığını tanımlamaları, değerlendirmeleri ve yönetmelerine yardımcı olmayı amaçlamışlardır. PCAM, proje karmaşıklığı için önemli olduğu kanıtlanmış karmaşıklı faktörlerinin karşılaştırılmasına dayanan karmaşıklık ölçümleme matrisi temeli üzerine geliştirilmiştir. Temel amaç, anahtar proje karmaşıklığı göstergelerinin belirlenmesi, bu göstergelerin projeye potansiyel etkilerinin değerlendirilmesi ve potansiyel etkilerin gerçekleşmesi durumunda yönetilmesi için bir plan tasarlanmasıdır.

Bosch-Rekveldt ve diğ. (2011) ilk olarak proje başlamadan önce değerlendirilebilecek, proje karmaşıklığına katkı sağlayan bileşenlere odaklanmış ve yaptıkları çalışmada bu bileşenleri tespit edebilmek ve bir çerçeve oluşturabilmek için hem teori hem de pratikten yararlanmışlardır [13]. Çalışmada belirlenen faktörler proje için "Ne?", "Kim?" ve "Nasıl?" sorularına göre sınıflandırılmıştır. "Ne?" faktörleri proje karmaşıklığının teknik boyutuna, "Kim?" faktörleri proje karmaşıklığının çevresel boyutuna, "Nasıl?" faktörleri ise proje karmaşıklığının organizasyonel boyutuna atanmıştır. $\mathrm{Bu}$ doğrultuda geliştirilen TOE karmaşıklık çerçevesinde teknik, çevresel ve organizasyonel faktörler anahtar faktörler olarak belirlenmiştir.

Geraldi ve diğ. (2011) proje karmaşıklığı ilgili boyutları belirlemek ve ortak bir dil oluşturmak adına yaptıkları sistematik çalışmaya, literatür araştırması ile başlamış, 1996'dan 2010'a kadar konu ile ilgili yazılmış tüm makaleleri incelemişlerdir [23]. İncelenen makalelerden 25 tanesi altı adımda detaylı olarak analiz edilmiş ve ortaya çıkan kavramlar beş karmaşıklık tipi altında ifade edilmiştir: (i) yapısal karmaşıklık, (ii) belirsizlik, (iii) dinamiklik, (iv) hız ve (v) sosyo-politik karmaşıklık. Şekil 1'de yer alan zaman çizelgesi, karmaşıklık ile ilgili yeni anlayışların ortaya çıktığı dönemleri göstermektedir. İlk boyut Baccarini (1996) [5] tarafından ortaya atılmış yapısal karmaşıklıktır ve 1996'dan itibaren karmaşıklığın bir özelliği olarak düşünülmektedir. Belirsizlik boyutu, Williams (1999) [10] tarafindan tanımlanan ikinci boyuttur. Karmaşıklık 2002-2004 yıllarında yapısal karmaşıklık ve dinamiklik boyutları ile ele alınmış; 2005 'te bu iki boyuta ek olarak Williams (2005) [24] hız boyutunu ortaya koymuştur. Son olarak 2007-2008 yıllarında karmaşıklığın sosyopolitik boyutu eklenmiştir [23]. 


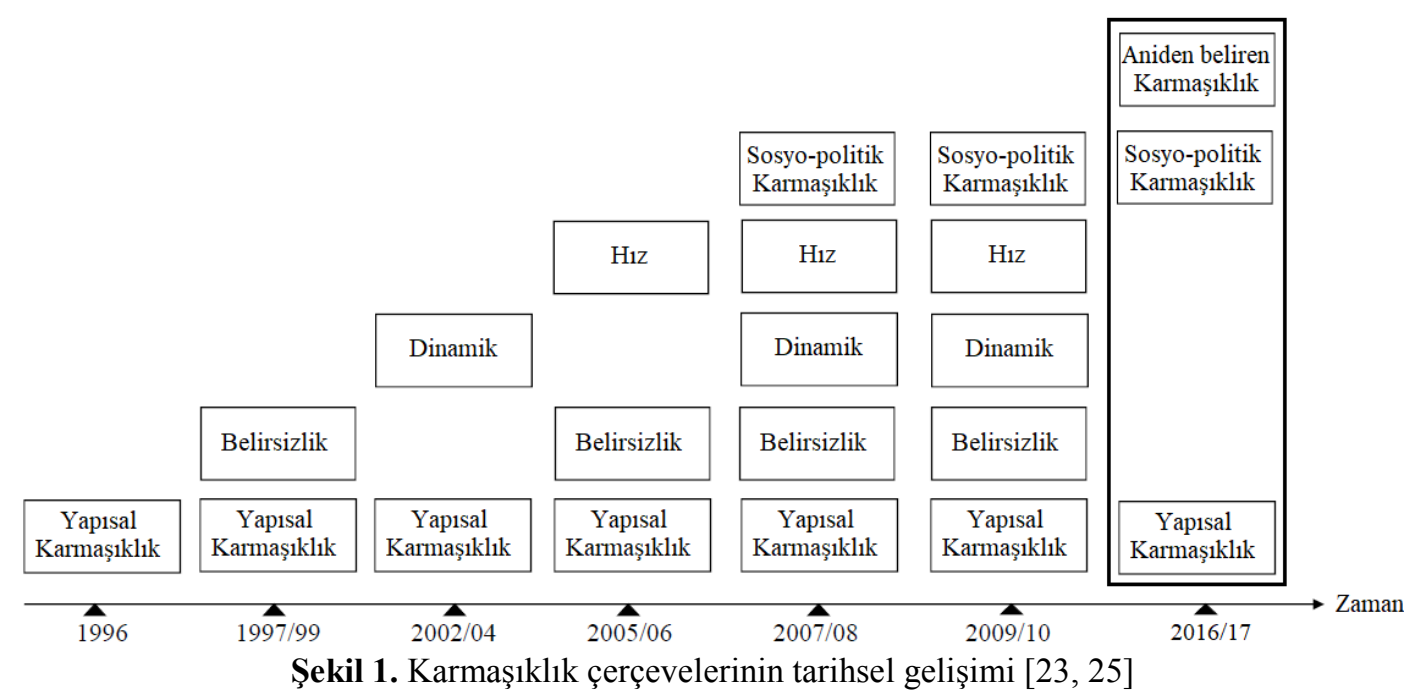

Karmaşıklık tiplerini ölçümlemek için kullanılacak göstergelerden belirsizlik, yapısal ve sosyo-politik karmaşıklık ile ilgili olanların sayısının fazla olması, araştırmacıları bunlar için alt kategoriler geliştirmeye yöneltmiştir (Bkz. Tablo 2).

Tablo 2. Karmaşıklığın boyutları ve değişkenleri [23]

\begin{tabular}{ll}
\hline Boyut & Değişken (Alt Boyut) \\
\hline \multirow{3}{*}{ Yapısal Karmaşıklık } & Büyüklük \\
& $\begin{array}{l}\text { Çeşitlilik } \\
\text { Bağımlılık }\end{array}$ \\
\hline \multirow{3}{*}{ Belirsizlik } & Yenilik \\
& Deneyim \\
& Bilginin elverişliliği \\
\hline Dinamiklik & Değişim \\
\hline Hız & Değişiklik hızı \\
\hline \multirow{3}{*}{ Sosyo-Politik } & Önem \\
Karmaşıklık & Destekleme \\
& Uyma/Birleşme \\
& Şeffaflık \\
\hline
\end{tabular}

Maylor ve Turner (2017) karmaşıklığa sübjektif bir açıdan bakarak projedeki karmaşıklığın anlaşııması, karmaşıklığın azaltılması ve azaltılamayan/arta kalan karmaşıklıklara cevap verilmesine yönelik bir çalışma yapmıştır [25]. Geraldi ve diğ. (2011)'nin [23] yaptıkları çalışmayı baz alan Maylor ve Turner (2017)
[25] 'hız' boyutunu kaynak yoğunluğunun bir ölçeği olarak değerlendirmiş ve bunu 'yapısal karmaşıklık' kavramı içinde ele almıştır. Benzer şekilde 'belirsizlik' boyutu ve 'dinamiklik' boyutunun aslında birbirleri ile ilişkisinin ve birbirlerine etkisinin yüksek olduğu varsayımında bulunmuş ve bu iki boyutu 'aniden beliren karmaşıklık' olarak tek bir boyut altında toplamışlardır. Sonuç olarak, Maylor ve Turner (2017)'ın [25], Geraldi ve diğ. (2011)'nin [23] ortaya koydukları karmaşıklık çerçevelerinin tarihsel gelişimine getirdikleri yeni boyut Şekil 1'de 2016/17 yılına ait bilgilerin bulunduğu kısımda gösterilmiştir.

Maylor ve Turner (2017) tarafindan geliştirilen Karmaşıklık Değerlendirme Aracı (CAT: The Complexity Assessment Tool) birçok endüstriden elde edilen verileri sentezleyerek, projelerin karmaşıklığını değerlendiren basit bir yöntemdir [25]. Maylor ve Turner (2017), CAT ile potansiyel karmaşıklıkları tanımlamış, diyalog kuracakları bir ortam oluşturarak uzmanları bir araya getirmiş ve belirlenen karmaşıklıkları ortadan kaldırmak, azaltmak ve kalanlar için yönetimsel bir cevap oluşturmak üzere bir çalışma gerçekleştirmiştir [25]. Uygulama sonucunda belirlenen boyutlar doğrultusunda katılımcilar tarafından kararlaştırılan faktörler Şekil 2'de gösterilmiştir. 


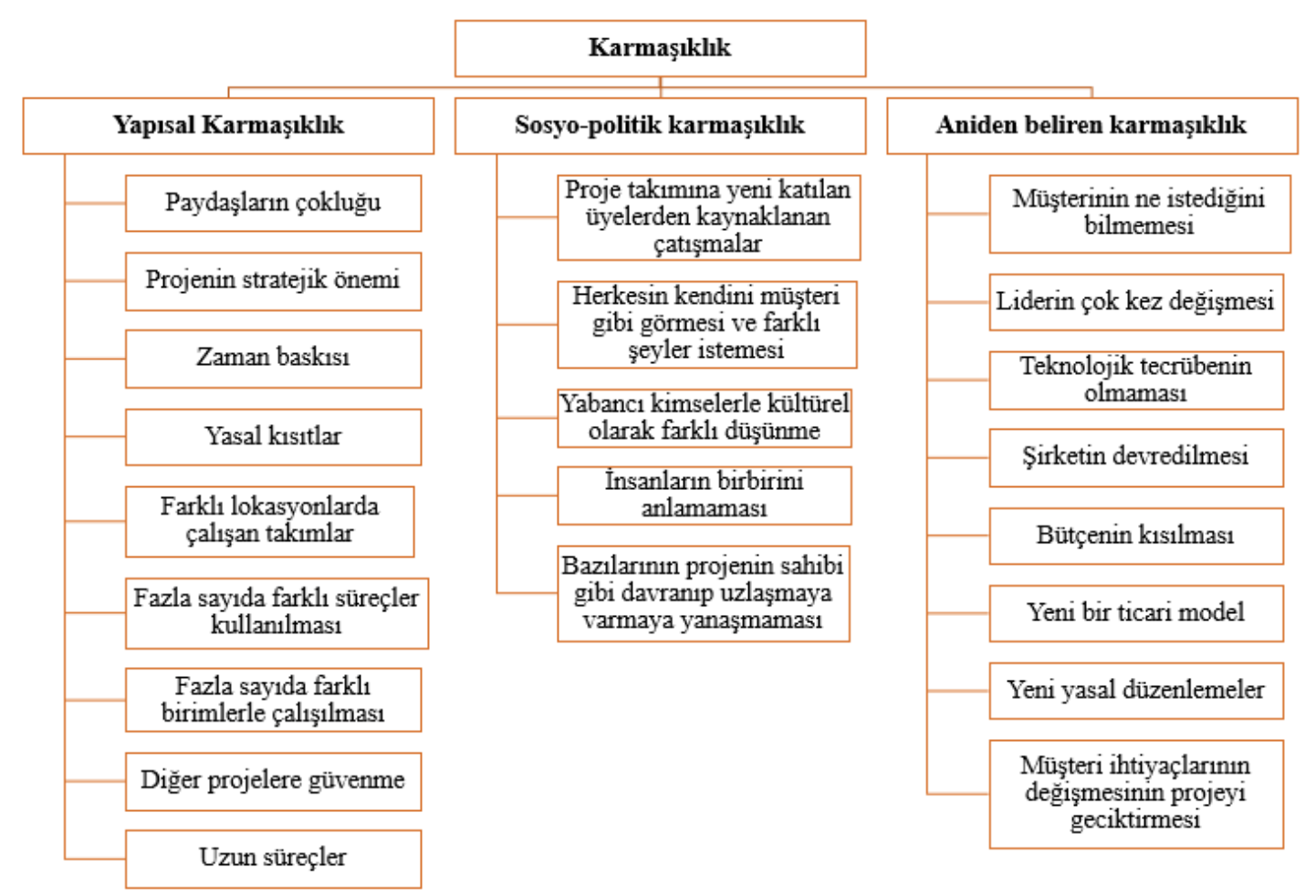

Şekil 2. Proje karmaşıklık faktörleri [25]

Wood ve Ashton (2015) proje karmaşıklığının ölçümlenmesine yönelik yaptıkları çalışmada, öncelikle endüstri uzmanları ile görüşmeler yaparak proje karmaşıklığı için bir tanım oluşturmuş ve proje karmaşıklığının faktörlerini belirlemiş, daha sonra da vaka analizleri ile proje karmaşıklığının faktörlerinin sıklık ve etkilerini analiz etmişlerdir [3]. Bu çalışmada toplam 46 faktör bulunmuş ve bunlar beş temel boyut altında gruplanmıştır: (i) organizasyonel boyut, (ii) operasyonel ve teknolojik boyut, (iii) planlama ve yönetim boyutu, (iv) çevresel boyut ve (v) belirsizlik boyutu.

Remington ve Pollack (2016) farklı karmaşıklık tiplerinin farklı yönetim araçlarına ihtiyaç duyduğunu belirtmiş ve en uygun yöntemleri belirleyebilmek için öncelikle dört farklı karmaşılık tipi belirleyerek, belirlenen karmaşıklık boyutlarının ölçümleneceği ve buna göre farklı yöntem ve stratejilerin tanımlanıp kullanılmasına olanak sağlayacak Karmaşıklık Haritalandırma Aracını (MPT: Mapping Complexity Tool) geliştirmişlerdir [15]. Bu çalışmada tanımlanan karmaşıklık boyutları aşağıda özetlenmiştir:

- Genellikle büyük projelerde karşılaşılan ve temelde projedeki bağımlılıkların sayısı ile bağlantılı yapısal karmaşıklık

- Çözümlenemeyen teknik konular ve tasarım konularının projede oluşturduğu etki ile ilgili teknik karmaşıklık

- Proje hedeflerindeki belirsizlikler, süreçlerde açıkça ifade edilmeyen adımlar, saklanan ajandalar, vb. bilinmezliklerden doğan yön ile ilgili karmaşıklık
- Çevre ya da stratejik yön değişimlerinden kaynaklanan, aniden ortaya çıan değişikliklerden kaynaklanan zaman gecikmelerini ifade eden geçici karmaşıklık.

Choudary vd. (2019), süreç endüstrisinde faaliyet gösteren ve Kurumsal Kaynak Planlaması (ERP: Enterprise Resource Planning) sistemi kurulum projesinin gerçekleştirildiği büyük ölçekli bir işletmede yürüttükleri anket çalışmasıyla, proje karmaşıklığına sebep olan faktörleri ve bu faktörlerin etkilerini azaltacak ya da ortadan kaldırılacak stratejileri belirlemeye çalışmışlardır. Çalışmada karmaşıklık ölçümü için CIFTER modeli kullanılmıştır [26].

Kermanshachi, Dao, vd. (2020) ağır sanayi projelerinin karmaşıklığının ölçümüne yönelik Dao vd. (2017)'nin çalışmasında [28] belirlenen 37 farklı karmaşıklık göstergesini içeren bir karmaşıklık ölçüm aracı geliştirmişlerdir. Çalışmada belirlenen karmaşıklık göstergeleri 'paydaş yönetimi', 'yönetişim', 'mali planlama', 'kalite', 'yasal', 'arayüzler', 'uygulama hedefi', 'tasarım ve teknolojiler', 'lokasyon', 'kapsam' ve 'kaynak' kategorileri altında gruplanmış ve bu göstergelerin proje karmaşıklığına olan etkileri uzmanların yaptıkları sıralamalara göre belirlenmiştir. Çalışmada karmaşıklık ölçüm aracında yer alacak göstergelerin belirlenmesi için Delfi yöntemi, bu göstergelerin önem değerlerini belirlemek için ise ağırlık sırası toplamı metodu kullanılmıştır [27].

Kermanshachi, Rouhanizadeh, vd. (2020), Kermanshachi, Dao, vd. (2020)'nin çalışmasına [27] benzer şekilde, kapsamlı bir literatür taraması 
sonucunda inşaat projeleri için karmaşıklık ölçümünde kullanılabilecek ve 11 kategori altında grupladıkları 38 proje karmaşıklık göstergesinin proje karmaşıklığına olan etkilerini uzman görüşlerinden hareketle belirlemiş ve çalışmanın sonucunda inşaat projeleri için 'kapsam yönetimi', 'proje kaynakları' ve 'arayüzler' kategorilerinin diğer kategorilere göre daha fazla önem değerine sahip olduğu sonucuna ulaşmışlardır. Çalışmada karmaşıklık göstergelerinin önem değerlerinin belirlenmesi için sıra toplamı yöntemi kullanılmıştır [29].

Luo vd. (2020) inşaat sektöründe proje karmaşıklığ ölçümü için Bayes Bilişsel Ağlarını (BBN: Bayesian Belief Network) temel alan ve neden sonuç ilişkilerinin dikkate alındığı bir yaklaşım önermişlerdir. $\mathrm{Bu}$ çalışmada literatür taramasından hareketle 26 karmaşıklık ölçüm göstergesi belirlenmiş, bu göstergeler 'bilgi', 'görev', 'teknolojik', 'çevresel' ve 'hedef' karmaşıklık boyutları altında değerlendirilmiş ve karmaşıklık yönetim için 'teknolojik', 'bilgi' ve 'görev' karmaşıklığı ile ilgili göstergelere daha fazla önem verilmesi gerektiği sonucuna ulaşılmıştır [30].

Ma \& Fu (2020) mega inşaat projelerinde proje karmaşıklığının proje başarı üzerindeki etkilerini inceledikleri çalışmalarında, proje karmaşıklığını ve proje başarısını beşer alt boyutta incelemiş (karmaşıklık için teknolojik, organizasyonel, hedef, çevresel ve kültürel boyutları; başarı için çizelge, maliyet, kalite, paydaş memnuniyeti ve sürdürülebilirlik boyutları) ve kalitatif karşılaştırma analizi yardımıyla farklı proje karmaşıklık boyutlarının kombinasyonlarının proje başarı boyutları üzerindeki etkilerini değerlendirmişlerdir. Çalışma sonucunda özellikle organizasyonel karmaşıklığın proje performansı üzerinde etkisi olduğu; yüksek organizasyonel karmaşıklığın ya da yüksek çevresel ve kültürel karmaşıklığın çizelgelerde gecikmelere yol açabileceği; yüksek teknolojik ve hedef karmaşıklıklarının maliyetleri olumsuz yönde etkileyeceği ve yüksek hedef karmaşıklığı ve kültürel karmaşıklığın kilit paydaşların memnuniyeti üzerinde etkisi olduğu sonucuna ulaşılmıştır [31].

\section{PROJE KARMAŞIKLIĞININ ÖLÇÜMÜ İÇİN GELIȘTÍRILEN MODEL}

Proje karmaşıklığını belirlemek için sadece projeleri değil, projeleri etkileyen içsel ve dişsal tüm faktörleri değerlendirmek esastır. Bir projenin gerçekleşmesinde proje hedeflerine göre çizilen rotada yer alan işler ve projede bilfiil çalışan kişiler kadar, bu işler ve kişileri etkileyen çevredeki oyuncuların durum ve davranışları da önemlidir. $\mathrm{Bu}$ kapsamda düşünüldüğünde bir projenin karmaşıklığını belirlemek için incelenmesi gereken proje ekosistemi, projenin kendisinden, projenin gerçekleştiği organizasyondan, projenin etkileşim içinde olduğu görev çevresinden ve içinde bulunulan genel (makro) çevreden oluşmaktadır (Bkz. Şekil 3).

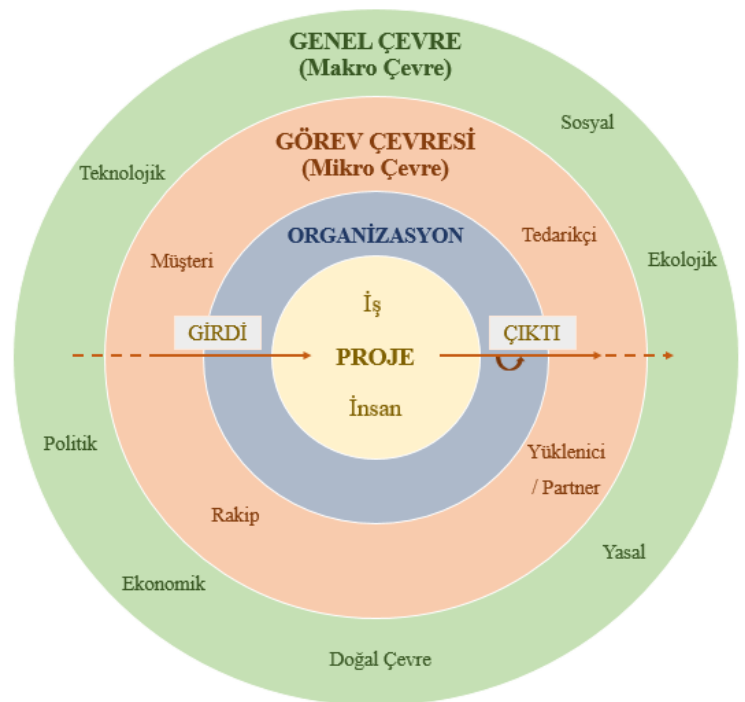

Şekil 3. Proje karmaşıklığı ekosistemi

Ekosistemde yer alan proje katmanı, projenin direkt olarak ilişkili olduğu iş süreçleri ve insani boyutları ifade etmektedir. Organizasyon, projenin gerçekleştiği organizasyona ait organizasyonel yapının, kültürün, süreç ve prosedürlerin proje üzerinde oluşturacağ 1 etkileri göz önüne almayı sağlayacak olan ikincil katmandır. Görev çevresi olarak adlandırılan üçüncül katman projenin gerçekleşmesi için direkt olarak etkileşim içinde bulunulan tedarikçiler, müşteriler, proje üzerinde direkt etkisi olan yükleniciler/partnerler ve rakiplerin yer aldığı çevredir. En son katman olan genel çevre ise projeyi dolaylı olarak etkileyen, proje kapsamında müdahale edilemeyen, ancak proje üzerinde etkisi olan teknolojik, ekolojik, sosyal, yasal, ekonomik, politik ve doğal çevre ile ilgili unsurları kapsar.

Karmaşıklığın ölçümlenmesi için karmaşıklığı meydana getiren faktörlerin belirlenmesi, daha sonra bu faktörlerin göstergelere dayandırılarak ölçümlenmesi esastır. Karmaşıklık çok geniş bir kavram olduğundan, karmaşıklığı oluşturan yüzlerce faktörden söz etmek mümkündür. Karmaşıklık yönetiminin proje yönetim sürecinde efektif olarak yer alabilmesi için, doğru bir şekilde ölçümlenmesi kadar, kolay bir şekilde ölçümlenmesi de önemlidir. Doğru ölçüm yapabilmek için doğru faktörlerin belirlenmesi kritik öneme sahiptir. Belirlenen faktörlerin gruplanarak birleştirilmesi ise kullanım kolaylığ bakımından fayda sağlayacaktır. Literatürde yapılan araştırmaların birçoğunda, çalışmaları daha sistematik ilerletebilmek ve faktörlerin anlaşılmasını kolaylaştırabilmek için karmaşıklık faktörleri belirli kategoriler altında gruplandırılmıştır.

Proje karmaşıklığının ölçülmesine yönelik boyutların, bu boyutların altında yer alan faktörlerin ve söz konusu 
faktörleri ölçülebilir kılan göstergelerin belirlenmesi, literatür araştırması [2, 7, 9, 13, 23, 25], uzmanlarla mülakat $[3,9,13,21]$, çalıştay $[10,18,25]$, vaka analizi [3, 12], anket [16], Delfi metodu [7] gibi tekniklerle gerçekleştirilebilir. İlgili boyutlar, bu boyutların altında yer alan faktörler ve göstergeler belirlendikten sonra ölçüm çeşitli araç ve yöntemlerle gerçekleştirilebilir. Literatürde bu amaçla Karmaşıklık Haritalandırma Aracı [15], CIFTER Proje Karmaşıklık Ölçüm Aracı [22], Sistem Dinamiği [32], Simülasyon [2], Analitik Hiyerarşi Süreci (AHP) [7], Proje Karmaşıklığı Değerlendirme ve Yönetme Arac1 (PCAM) [19], Karmaşıklık Değerlendirme Aracı (CAT) [25], Yapısal Eşitlik Modelleme, vb. istatistiksel teknikler [16, 17] kullanılmıştır.

Proje karmaşıklığı değerlendirilirken, projelerde çeşitli faaliyetlerin gerçekleştirildiği, bu faaliyetlerin insanlar tarafindan yürütüldüğü/yönetildiği, projelerin bir organizasyonun içerisinde gerçekleştiği ve bu organizasyonun sürekli etkileşim halinde olduğu bir çevrede faaliyet gösterdiği hususları göz önünde bulundurulmalıdır. Diğer bir ifadeyle, proje karmaşıklığı ölçülürken bu boyutların tamamının -iş, insan, organizasyon ve çevre- dikkate alınması gerekmektedir. $\mathrm{Bu}$ çalışma kapsamında proje karmaşıklığının ölçülmesi için, yukarıda belirtilen bu gerekliliğin karşılanması; yani projelerin sadece kendisinin değil, projeleri etkileyen içsel ve dişsal tüm faktörlerin değerlendirilmesi düşüncesinden hareketle, literatürdeki çalışmalardan farklı olarak, bütünsel bir bakış açısıyla, projenin kendisinden, projenin gerçekleştiği organizasyondan, projenin etkileşim içinde olduğu görev çevresinden ve içinde bulunulan genel çevreden oluşan ve detayları Şekil 3 'te gösterilen proje ekosistemi temel alınmıştır. $\mathrm{Bu}$ bağlamda, literatür araştırması sonucunda belirlenen karmaşıklık ölçümüne ilişkin göstergeler, belirtilen bu proje ekosistemin kapsamına göre dört temel boyut altında ele alınmıştır: (i) operasyonel karmaşıklık, (ii) yönetsel karmaşıklık, (iii) organizasyonel karmaşıklık ve (iv) çevresel karmaşıklık. Operasyonel ve yönetsel karmaşıklık proje ekosisteminin proje katmanında (iş ve insan boyutu), organizasyonel karmaşıklık organizasyon katmanında (organizasyon boyutu), çevresel karmaşıklık da görev çevresi ve genel çevre katmanlarında (çevre boyutu) oluşabilecek karmaşıklıklara karşılık gelmektedir. Her bir temel boyut altında yer alan faktörler, literatürde çoğunlukla ayrı birer karmaşıklık boyutu olarak ele alınan, büyüklük, çeşitlilik, ilişkiler, etkileşim, belirsizlik, yenilik, değişkenlik, zorluk ve risk gibi alt boyutlar ile ayrıştırılmıştır. Literatürdeki çalışmalar incelenerek elde edilen boyutların yeni bir bakış açısıyla derlenmesi sonucu oluşturulan proje karmaşıklığı modeli Şekil 4'te gösterilmektedir. $\mathrm{Bu}$ çalışma, proje karmaşıklığının tanımlandığı, boyutlarının belirlendiği ve karmaşıklık seviyesini ölçecek bir metodolojinin sunulduğu bütünleşik bir çalışma olma özelliğini taşımaktadır.

Geliştirilen proje karmaşıklığı ölçüm modeli, projenin direkt olarak ilişkili olduğu iş süreçleri ve insani boyutları; projenin gerçekleştiği organizasyona ait organizasyonel yapı, kültür, süreç ve prosedürlerin proje üzerinde oluşturacağı etkileri; projenin gerçekleşmesi için direkt olarak etkileşim içinde bulunulan tedarikçi, müşteri, yüklenici, partner ve rakipleri ve proje üzerinde dolaylı da olsa etkisi olan teknolojik, ekolojik, sosyal, yasal, ekonomik, politik ve doğal çevre ile ilgili unsurları kapsamaktadır. Dolayısıyla da, projenin başarısını olumsuz yönde etkileyebilecek karmaşıklık unsurlarının bütünsel olarak değerlendirilebilmesine ve kritik karmaşıklık unsurlarının göz ardı edilmesinin önlenmesine imkân sağlamaktadır.

Literatürde belirtildiği üzere karmaşıklığı oluşturan yüzlerce faktörden söz etmek mümkündür. Karmaşıklık ölçümünün efektif bir şekilde gerçekleştirilebilmesi ve proje yönetim sisteminin bir parçası haline gelebilmesi için, karmaşıklığın doğru bir şekilde ölçümlenmesi kadar kolay bir şekilde ölçümlenmesi de önem taşımaktadır. Bu bağlamda, geliştirilen ölçüm modelinde karmaşıklık ölçüm göstergelerinin belirtilen proje ekosistemi çerçevesinde gruplanarak birleştirilmiş olması, kullanım kolaylığı bakımından fayda sağlamaktadır.

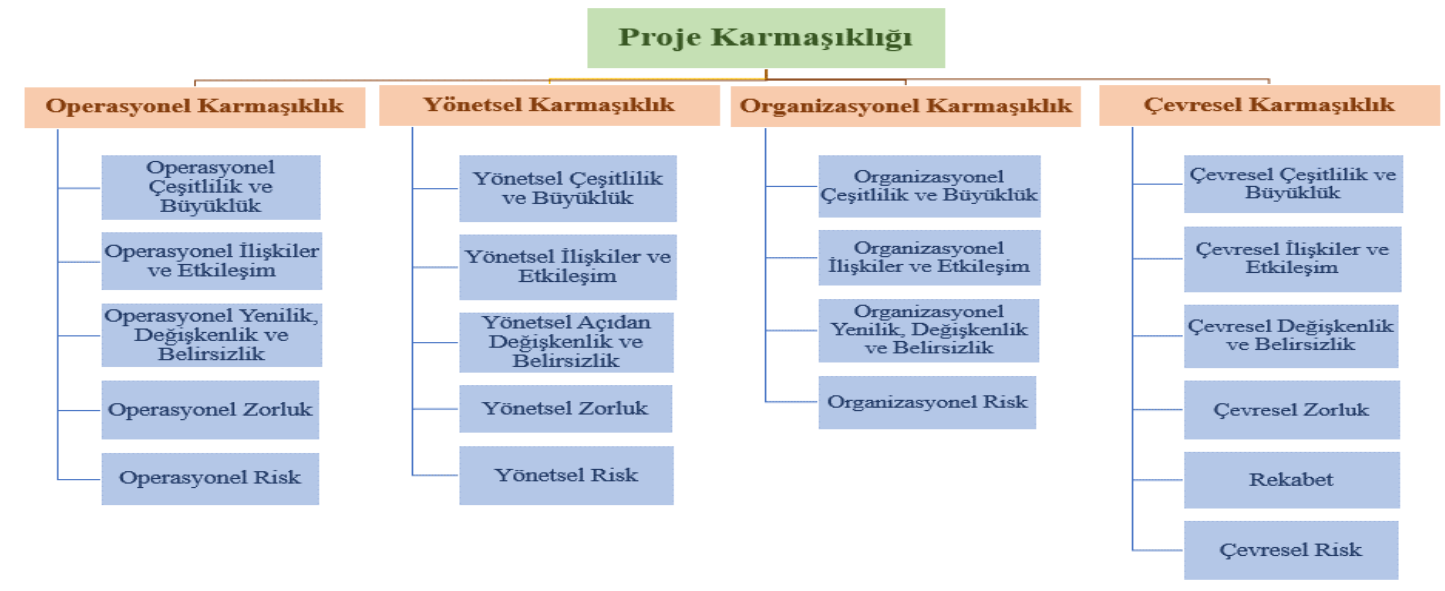

Şekil 4. Proje karmaşıklığı çerçevesi 


\subsection{Operasyonel Karmaşıklık}

Operasyonel karmaşıklı projelerde karmaşıklık yaratan faktörlerin iş yönetimi ile ilgili olan kısımlarını ifade etmektedir. Proje kapsam1, projede gerçekleştirilen işler, kullanılan yöntem, teknoloji, süreç ve standartlar ile faaliyetlerin gerçekleştirilmesi ile ilgili tüm faktörler bu kapsamda değerlendirilmektedir. Operasyonel karmaşıklıkta etkisi büyük olan alanlardan biri projede kullanılan teknolojilerdir. Proje karmaşıklığı açısından ele alındığında teknoloji, girdileri çıktılara dönüştüren bir dönüşüm süreci olarak tanımlanabilir. $\mathrm{Bu}$ dönüşüm süreci malzeme, araç, teknik, tecrübe ve bilgilerden faydalanmaktadır $\mathrm{ki}$ bunlar $\mathrm{da}$ bu çalışmada operasyonel karmaşıklı boyutu altında dikkate alınan konulardir.

Çalı̧̧ma kapsamında literatür araştırması sonuçlarından hareketle proje karmaşıklığını etkileyen temel göstergelerden, operasyonel boyut kapsamında değerlendirilebilecek olanlar 'operasyonel çeşittilik ve büyüklük', 'operasyonel ilişkiler ve etkileșim', 'operasyonel yenilik, değişkenlik ve belirsizlik', 'operasyonel zorluk' ve 'operasyonel risk' olarak belirlenmiştir. $\mathrm{Bu}$ boyutların kapsamları aşağıda özetlenmiştir.

\subsubsection{Operasyonel çeşitlilik ve büyüklük}

Operasyonel çeşitlilik ve büyüklük, projedeki işler, yöntemler, kullanılan teknolojiler ve kalite/maliyet/zaman gibi hedeflerin sayısının ve çeşitliliğinin yanı sıra projenin kapsam genişliği, kapsam dahilindeki planlama ve uygulamaların gerektirdiği çabanın ve proje bütçesinin büyüklüğünü ifade etmektedir. $\mathrm{Bu}$ kapsamda değerlendirilen göstergeler:

- Projedeki operasyonel ögelerin (işlerin, girdi ve çıktıların, yöntem ve yaklaşımların, kullanılan teknolojilerin) sayısı ve çeşitliliği

- Operasyonel hedeflerin (genel hedefler; kalite, maliyet ve zamansal hedefler) sayıs ve çeşitliliği

- Projenin finansal ölçek büyüklüğü (ayrılan bütçe ve maliyetler)

- Projenin kapsam genişliği (içerikte yer alan maddelerin sayısı ve yoğunluğu)

- Operasyonel planlama ve uygulama büyüklüğü (işlerin bir araya getirilmesinin ve gerçekleştirilmesinin gerektirdiği çabanın büyüklüğü)

\subsubsection{Operasyonel ilişkiler ve etkileşim}

Operasyonel ilişkiler ve etkileşim, projedeki işler, yöntemler, kullanılan teknolojiler ve hedefler arasındaki bağımlılık ilişkilerini, planlama ve süreçlerdeki sıralılık ilişkilerini ve etkileşimleri ifade etmektedir. Bu kapsamda değerlendirilen göstergeler:

- Operasyonel hedeflerin bağımlılığı (hedefler arasındaki ilişkisellik)
- Projedeki ögelerin bağımlılığı, etkileşimleri, sıralılık ilişkileri (operasyonel açıdan takvimler, planlamalar, görevler, süreçler arası bağımlılık ve etkileşimler)

\subsubsection{Operasyonel yenilik, değișkenlik ve belirsizlik}

Operasyonel yenilik, değişkenlik ve belirsizlik, gerçekleştirilen işin detaylarına yönelik belirsizlikler, kalite, zaman gibi operasyonel hedeflere, yöntem ve süreçlere ilişkin belirsizlikler ile operasyonel etki yaratan kapsam, vb. değişiklikleri ve projedeki yeni veya tanınmayan ögeleri ifade etmektedir. $\mathrm{Bu}$ kapsamda değerlendirilen göstergeler:

- Kapsam ve operasyonel hedeflerdeki belirsizlikler (yapılacak işe ait detaylardaki veya kalite/zaman/maliyet hedeflerindeki belirsizlikler)

- Operasyonel yöntem ve süreçlerle ilgili belirsizlikler

- Operasyonel etki yaratan değişkenlik (kapsam değişikliği, talep değişikliği, vb. sıklığı ve büyüklüğü)

- Operasyonların ve süreçte kullanılan ögelerin yeniliği (ilk kez denenen teknolojilerin, tekniklerin, metodolojilerin varlığı)

\subsubsection{Operasyonel zorluk}

Operasyonel zorluk, işlerin doğasından kaynaklı uygulama zorluklarını, entegrasyon sürecindeki zorlukları ve bağımlılıkların fazla olduğu durumlardaki planlama zorluklarını ifade etmektedir. Gerçekçi olmayan operasyonel beklentiler de operasyonel zorluk altında değerlendirilmektedir. $\mathrm{Bu}$ kapsamda değerlendirilen göstergeler:

- Teknik zorluklar (işlerin ve kullanılan yöntemleri uygulamanın zorluğu, kritik aktivitelerin sayıs1 veya standartların karmaşıklığ 1 )

- Entegrasyon-operasyonel planlama ile ilgili zorluklar (işlerin öncelik/bağımlılık durumuna göre planlanmasındaki zorluklar)

- Gerçekçi olmayan operasyonel beklentiler (kalite, zaman, maliyet, hız ile ilgili gerçekçi olmayan beklentiler)

\subsubsection{Operasyonel risk}

Meydana gelmesi durumunda projedeki işlerin gerçekleşmesini olumsuz etkileyebilecek durumları (bağımlı işlerden ön şart olanın teknik bir sorun sebebiyle aksaması, vb. işin yapılması açısından engel yaratabilecek, gecikmelere sebep olabilecek teknik riskler) ifade etmektedir.

\subsection{Yönetsel Karmaşıklık}

Yönetsel karmaşıklık projelerde karmaşıklık yaratan faktörlerin insan yönetimi ile ilgili olan kısımlarını ifade etmektedir. Proje ekibinde yer alan çalışanlarla ve organizasyonun diğer birimlerinde projeye dahil 
olmayan çalışanlarla ilgili sayı, çeşitlilik, ilişkiler, eğitim, yetkinlik, yönetim gibi hususlar bu kapsamda değerlendirilmektedir. Yönetsel karmaşıklık proje ile ilişkili tüm kişilerin yönetimi ile ilgilense de en büyük pay projede doğrudan çalışan kişilere aittir. Projenin gerçekleşmesi için bu kişilerin eğitim, tecrübe ve yetkinlik seviyelerine göre uygun pozisyonlarda görevlendirilmesinden kişilerin takvimlerine, planlamalarına kadar insan ile ilgili tüm sorumlulukları içerir.

Çalışma kapsamında literatür araştırması sonuçlarından hareketle proje karmaşıklığını etkileyen temel göstergelerden, yönetsel boyut kapsamında değerlendirilebilecek olanlar 'yönetsel çeşitlilik ve büyüklük', 'yönetsel ilişkiler ve etkileşim', 'yönetsel değişkenlik ve belirsizlik', 'yönetsel zorluk' ve 'yönetsel risk' olarak belirlenmiştir. $\mathrm{Bu}$ boyutların kapsamları aşağıda özetlenmiştir.

\subsubsection{Yönetsel çeşitlilik ve büyüklük}

Yönetsel çeşitlilik ve büyüklük, projede direkt olarak çalışan bireylerin sayısı ile dil, kültür, lokasyon, beklenti, ilgili alanı, vb. çeşitliliğgi, uzmanlıkların ve dahil olan disiplinlerin çeşitliliği ve iletişim kurulan alanların sayısını ifade etmektedir.

- Proje ekibindeki kişilerin sayısı ve dil, kültür, lokasyon, beklenti, ilgili alanı, vb. çeşitliliğinden kaynaklanan farklılık düzeyi

- Projedeki uzmanlıkların sayısı ve çeşitliliği

- Proje ekibi için etkileşim alanlarının (arayüzlerin) sayısı ve çeşitliliği

\subsubsection{Yönetsel ilişkiler ve etkileşim}

Yönetsel ilişkiler ve etkileşim, projede direkt olarak çalışan bireyler arası iletişim, güven, şeffaflık ve bilgi paylaşımını; takvimler, planlamalar, görevler ve süreçler arası bağımlılık ve etkileşimleri ifade etmektedir.

- Proje ekibi için etkileşim ve bağımlılık düzeyi (takvimler, planlamalar, görevler, süreçler arası bağımlılık ve etkileşimler)

- Proje ekibi için iletişim, ilişki ve ortak anlayış düzeyi (iletişim, güven, şeffaflık, bilgi aktarımı)

\subsubsection{Yönetsel değişkenlik ve belirsizlik}

Yönetsel değişkenlik ve belirsizlik, zayıf tanımlanmış, gerektirdiği uzmanlık seviyesi belirsiz olan rollerin varlığından kaynaklanan belirsizlikleri ve takım üyelerinin değişmesi, uzmanlık ihtiyaçlarındaki değişimler, vb. değişkenliklerin sıklığını ve etkilerinin büyüklüğünü ifade etmektedir.

- Proje ekibine ilişkin değişkenlik (takım üyelerinin değişmesi, uzmanlık ihtiyaçlarındaki değişimler, vb. sıklığı ve büyüklüğü)

- Proje ekibinin kullanacağı yöntem ve süreç ile ilgili belirsizlikler (zayıf tanımlanmış, gerektirdiği uzmanlık seviyesi belirsiz olan roller)

\subsubsection{Yönetsel zorluk}

Yönetsel zorluk, süreçlerdeki iletişim ve koordinasyon, görevlerin uygun yetki ve sorumluluk çerçevesinde dağıtılması, vb. konularda karşılaşılan zorlukları ifade etmektedir.

\subsubsection{Yönetsel risk}

Meydana gelmesi durumunda projedeki bireylerin çalışmasını olumsuz etkileyebilecek durumları (projedeki uzman kişinin işten ayrılması sebebiyle işin aksaması, vb.) ifade etmektedir.

\subsection{Organizasyonel Karmaşıklık}

Literatürdeki birçok çalışmada proje karmaşıklığını etkileyen en önemli faktörlerden biri olarak organizasyonel karmaşıklık yerini almıştır. Organizasyonel karmaşıklık, projenin gerçekleştiği organizasyonda var olan ve projenin gerçekleşme sürecine etki edebilecek her türlü süreç ve sistemlerdeki karmaşıklığı ifade etmektedir. Organizasyon yapısı, organizasyondaki dikey farklılaşma (hiyerarşik yapı), organizasyondaki yatay farklılaşma (organizasyonel birimler), merkezilik/resmileşme derecesi (kararların alındığ 1 seviye), iletişim derecesi (formel-informel akış seviyesi), kurum kültürü, vizyon ve hedefler, süreç ve standartlar, kaynaklar gibi faktörler proje ile ilgili organizasyonel karmaşıklığa sebep olabilecek başlıca faktörler arasında yer almaktadır.

Vidal ve Marle (2008)'ye göre proje karmaşıklığı faktörlerinin yaklaşı \% $\%$ 70'i organizasyonel faktörlerdir [20]. Organizasyonların gün geçtikçe büyümesi, rekabetin artması, iş dünyasının genişlemesiyle birlikte odak noktalarının farklılaşması gibi durumlar, organizasyonları daha karmaşık bir hale getirmektedir. Organizasyonlar, günümüz dünyasında artan rekabet koşullarında hayatta kalabilmek üzere yapılarını yatay ve dikey olarak farklılaştırmaya yönelmekte ve bundan doğan iç bağımlılıklar organizasyonel karmaşıklığı artırmaktadır [17]. Maylor ve Turner (2017)'da dinamik çevrelerin, genişlemiş kontrol döngülerinin ve yasa, mevzuat, kurumsal sosyal sorumluluk gibi devam eden sistemlere gelen ek kısitların bir sonucu olarak organizasyonların artan bir şekilde karmaşık sistemler olarak göründüğünü vurgulamıştır [25].

Çalışma kapsamında literatür araştırması sonuçlarından hareketle proje karmaşıklığını etkileyen temel göstergelerden, organizasyonel boyut kapsamında değerlendirilebilecek olanlar 'organizasyonel çeşitlilik ve büyüklük', 'organizasyonel ilişkiler ve etkileşim', 'organizasyonel yenilik, değişkenlik ve belirsizlik' ve 'organizasyonel risk' olarak belirlenmiştir. $\mathrm{Bu}$ boyutların kapsamları aşağıda özetlenmiştir.

\subsubsection{Organizasyonel çeşitlilik ve büyüklük}

Organizasyonel çeşitlilik ve büyüklük, paydaşların sayısı ile dil, kültür, lokasyon, beklenti, ilgili alanı, vb. 
açıdan organizasyondaki çeşitliliğin yanı sıra organizasyondaki birim ve bölümlerin sayısı, çeşitliliği ve yapısını ifade etmektedir.

- Paydaşların sayısı ve organizasyondaki çeşitlilik (paydaşların sayısı ve dil, kültür, lokasyon, beklenti, ilgi alanı bakımından organizasyondaki çeşitlilik)

- Organizasyonel yapı (organizasyondaki birim ve bölümlerin sayısı, organizasyonel yetkinliklerin tipleri)

\subsubsection{Organizasyonel ilişkiler ve etkileşim}

Organizasyonel ilişkiler ve etkileşim, organizasyon stratejisi ile proje hedeflerinin uyumu, kararların alındığı seviye ve bölümler/birimler arası bağımlılık ve etkileşimler, paydaşların uyumu, iletişimi ile iletişimde güven, şeffaflık gibi konuları ifade etmektedir.

- Organizasyonel bağımlılıklar (organizasyon stratejisi ile proje hedeflerinin uyumu, yapıya göre kararların alındığı seviye ve bölümler/birimler arası bağımlılık ve etkileşimler)

- Organizasyonel iletişim ve ilişki düzeyi (paydaşların uyumu, paydaşlar arası iletişim, iletişimde güven, şeffaflık)

\subsubsection{Organizasyonel yenilik, değişkenlik ve belirsizlik} Organizasyonel belirsizlik, vizyon, misyon, organizasyonel yapının yanı sira performans göstergeleri, süreç ve standartlardaki belirsizlikler ile organizasyonel belirsizlikleri; organizasyonel değişkenlik organizasyon genelinde kullanılan teknolojilerin, organizasyonun sahip olduğu finansal kaynakların, vs. süreç içinde değişimini ifade etmektedir. Yeni organizasyonel yapılar organizasyonel yenilik olarak değerlendirilmiş ve bu boyut altında ele alınmıştır.

- Organizasyonel yenilik (yeni organizasyonel yap1)

- Organizasyonel değişkenlik (teknolojik, finansal, vb. kaynaklardaki değişimler, bu değişimlerin sıklığı ve büyüklüğü)

- Organizasyonel belirsizlik (vizyon, misyon, organizasyonel yapının yanı sira performans göstergeleri, süreç ve standartlardaki belirsizlikler)

\subsubsection{Organizasyonel risk}

Meydana gelmesi durumunda organizasyonun işleyişini olumsuz etkileyebilecek durumları (organizasyonel yapı değişikliği, şirket birleşmeleri, vb.) ifade etmektedir.

\section{4. Çevresel Karmașıklık}

Çevresel karmaşıklık, projenin tedarikçileri, müşterileri, rakipleri ve yüklenicilerinden, projenin gerçekleştiği ülkede ve hatta global dünyada gerçekleşen teknolojik, politik, sosyal ve ekonomik gelişmeler, yasalar, doğal çevre ile ilgili konulara kadar çok geniş bir çerçeveyi kapsamaktadır. Tüm çevresel faktörler proje karmaşıklığını etkilemektedir, öyle ki Bosch-Rekvaldt ve diğ. (2011) ilgi ve ihtiyaçları çevreye bağlı değişebilen proje paydaşlarının bile çevresel karmaşıklığı etkilediğini ifade etmiştir [13].

Çevresel karmaşıklık faktörleri ele alınırken projeleri doğrudan etkileyen görev çevresinin (mikro çevre) yanı sıra projeleri dolaylı olarak etkileyen genel çevrenin (makro çevre) de göz önünde bulundurulması gerekmektedir. Görev çevresi, projeye girdi sağlayan ve projenin çıktılarını talep eden unsurları kapsamında barındıran çevredir. Projenin tedarikçileri, müşterileri, rakipleri, yüklenici ve partnerlerinden oluşur. Görev çevresinde ortaya çıkan herhangi bir değişiklik projeyi doğrudan etkiler. Genel çevre ise, projeye doğrudan girdi sağlamayan ancak içindeki herhangi bir değişiklik ile projeye etki edebilecek ve projenin karmaşıklaşmasına yol açacak geniş çevreyi ifade etmektedir. Ülkede ve dünyada gerçekleşen teknolojik gelişmeler, sosyal olaylar, politik olaylar, ekonomik değişiklikler, getirilen yasal değişiklik ve düzenlemeler, doğal çevre ve ekolojik değişimler projelere yön vermektedir. $\mathrm{Bu}$ sebeple proje karmaşıklığı değerlendirilirken bu faktörlerin de mutlaka dikkate alınması gerekmektedir.

Çalışma kapsamında literatür araştırması sonuçlarından hareketle proje karmaşıklığını etkileyen temel göstergelerden, çevresel boyut kapsamında değerlendirilebilecek olanlar 'çevresel çeşitlilik ve büyüklük', 'çevresel ilişkiler ve etkileşim', 'çevresel değişkenlik ve belirsizlik', 'çevresel zorluk', 'rekabet' ve 'çevresel risk' olarak belirlenmiştir. Bu boyutların kapsamları aşağıda özetlenmiştir.

\subsection{1. Çevresel çeşitlilik ve büyüklük}

Çevresel çeşitlilik ve büyüklük, paydaşların ve projenin görev çevresinde yer alan dış bağımlılıkların sayısı ve çeşitliliği ile genel çevrede var olan çeşitliliği ifade etmektedir.

- Görev çevresindeki çeşitlilik ve paydaşların sayısı (dış bağımlılıkların (kaynaklar, vs.) ve paydaşların sayısı ve çeşitliliği)

- Genel çevredeki çeşitlilik (projeye dahil edilmemiş farklı teknolojilerin, vb. varlığı ve çeşitliliği)

\subsection{2. Çevresel etkileşim ve ilişkiler}

Çevresel etkileşim ve ilişkiler, paydaşların davranışları, ilişkileri, uyumu, bilgi paylaşımı gibi iletişim ve etkileşim ile ilgili kavramları ve dış bağımlılıkların derecesini ifade eder. Hem görev çevresi hem de genel çevrede karşılaşılabilecek dış paydaşların onay ihtiyaçları ve sağlık, güvenlik, çevre farkındalığı gibi konulardaki beklentiler bu boyut altında değerlendirilmektedir. Organizasyon dişı teknolojik, yasal, sosyal ve çevresel olayların projeye etkileri de bu kapsama alınmıştır.

- Görev çevresindeki paydaşların tutumları, ilişki 
ve iletişim düzeyi (uyum, bilgi paylaşımı)

- Görev çevresindeki dış bağımlılık derecesi

- Görev çevresi ve genel çevredeki diş paydaşların onay ihtiyaçları ve teftiş gereklilikleri

- Görev çevresi ve genel çevredeki beklentiler (sağlık, güvenlik konuları ve çevre farkındalığı)

- Genel çevredeki teknolojik, yasal, sosyal ve ekolojik etkiler

\subsection{3. Çevresel değişkenlik ve belirsizlik}

Çevresel değişkenlik ve belirsizlik, aniden ortaya çıkan yeni teknolojiler, yasalar, vb. değişiklikleri ve hava koşulları, iklim, pazarın durumu, hükümetin durumu gibi belirsizlikleri ifade etmektedir.

- Çevresel değişkenlik (aniden ortaya çıkan yeni teknolojiler, yasalar, vb. değişiklikler, paydaşlarla ilgili yaşanan değişiklikler ile bu değişikliklerin sıklığı ile büyüklüğü)

- Çevresel belirsizlik (hava koşulları, iklim, pazarın durumu, hükümetin durumu, vb. genel çevredeki ve görev çevresindeki belirsizlikler)

\subsection{4. Çevresel zorluk}

Çevresel zorluklar, proje için gerekli izin sayısı, izin almanın zorluğu, yasal düzenlemeler, güvenlik konusundaki beklentiler, iklim koşulları, vb. zorlayıcı koşullara uyum sağlama gibi zorlukları ifade etmektedir.

\subsubsection{Rekabet}

Rekabet seviyesi ve rekabet halinde olunan rakiplerin durumlarının proje işleyişine etkilerini ifade etmektedir.

\subsection{6. Çevresel risk}

Meydana gelmesi durumunda projenin işleyişini olumsuz etkileyebilecek durumları (piyasa şartlarındaki dalgalanmalar, vb.) ifade etmektedir.

\section{DIJJITAL BANKACILIK PROJELERINDE PROJE KARMAȘIKLIĞININ ÖLÇÜMLENMESINE YÖNELIK BİR UYGULAMA}

Karmaşıklığın ayrı bir kavram olarak proje yönetiminde yer almadığı durumlarda, proje işleyişi sırasında ortaya çıkan proje karmaşıklığı, proje yöneticilerinin bilgi, beceri ve tecrübeleri doğrultusunda yönetilmeye çalışılmaktadır. Bu süreçte başarı büyük ölçüde proje yöneticisine bağlı kalmaktadır. Ancak her proje yöneticisinin uzmanlık alanlarının ve tecrübelerinin farklı olması ve proje karmaşıklığının çok geniş bir kavram olması sebebiyle, proje yöneticilerinin her türlü karmaşıklığı başarılı bir şekilde yönetmeleri mümkün olmayabilir. Projenin sorumlusu, proje için gerekli yetkinliklere sahip bir proje yöneticisi olsa dahi, karmaşıklık yaratan durumlar ile karşılaşıldığında, gerekli aksiyonları almak için geç kalınması durumu söz konusu olabilir. Dolayısıyla, projelerde başarıyı sağlamak, karmaşıklık yaratabilecek faktörlerin önceden belirlenmesi ve ölçümlenmesi ile büyük oranda ilişkilidir. Bu bölümde, karmaşıklığın ölçümlenmesi ve farklı iki projenin karmaşıklık seviyelerinin karşılaştırılması amacıyla gerçekleştirilen bir uygulamaya yer verilecektir.

Gerek literatürde yer alan çalışmalarda gerekse de pratik uygulamalarda, soyut bir kavram olması sebebiyle proje karmaşıklığının ölçümlenmesi, kavramın kapsamını ifade eden somut göstergelerin belirlenmesine dayanmaktadır. Topçu (2019) karmaşık bir sorunla karşılaşıldığında, ilgili sorunu daha iyi anlamak ve çözüm üretebilmek için sorunun bileşenlerine ayrılması ve bu bileşenlerin hiyerarşik bir şekilde düzenlenmesinin, sorunun çözümünde kolaylık sağlayacağını ifade etmiştir [33]. Bu doğrultuda öncelikle proje karmaşıklığında etkili olacak temel faktörlerin belirlenmesi, daha sonra belirlenen faktörlerin ve bu faktörleri somutlaştıran göstergelerin, ortak noktaları doğrultusunda oluşturulacak boyutlar altında gruplanması, proje karmaşıklığının ölçümünü kolaylaştıracak ve karmaşıklığa bütünsel bir bakış açısıyla daha geniş bir çerçeveden bakılabilmesini olanak sağlayacaktır. Karmaşıklığa ilişkin faktörlerin ilgili boyutlar altında ifade edilmesi ile karmaşıklık yaratacağı düşünülen faktörler ortaya konmuş olmakla birlikte, bu faktörlerin gerçekten karmaşıklık yaratıp yaratmayacakları veya yarattıklarında proje başarısını ne derece etkileyecekleri, ancak proje karmaşıklığının ölçümlenmesi ile mümkün olacaktır.

Proje karmaşıklığının ölçümü için geliştirilen ölçüm araçlarından biri olan CIFTER, GAPPS tarafından oluşturulmuş, karşılaştırmalı proje karmaşıklık ölçme aracıdır. Belirlenen yedi faktör için 1 ile 4 arası yapılan puanlandırmalar ile karmaşıklık ölçümü gerçekleştirilmektedir [22]. PCAM - Proje Karmaşıklığı Değerlendirme ve Yönetme Aracında ise önceden belirlenmiş gösterge seti, ilgili proje kapsamında uzman görüşleri ile sıralanır ve programa girdi olarak verilir; program girdileri değerlendirerek en önemli göstergeleri ortaya koyar [19]. CAT Karmaşıklık Değerlendirme Aracı, uzmanların karmaşıklık boyutları, faktörleri ve faktörlerin önem derecelerini belirleyebilmek için tartışabilecekleri bir platform sunan bir araçtır [25]. Remington ve Pollack (2016) tarafindan ortaya atılan Karmaşıklık Haritalandırma Aracı ise belirlenen boyutlara göre uzmanların karmaşıklık seviyelerini değerlendirmesi ve sonuçların görselleştirme yoluyla daha iyi anlaşılmasını sağlayan bir araçtır [15]. Bu tür ölçüm araçlarının ortak özelliği, araçları geliştiren kişilerin belirlediği boyutlar temel alınarak ölçüm yapılabilir olmasidir.

Öte yandan Analitik Hiyerarşi Süreci (AHP) ve Analitik Ăg Süreci (ANP), proje karmaşıklığ1 ölçümlenmesinden bağımsız olarak bir problemi 
etkileyen değişkenlerin ikili kıyaslamalar yoluyla değerlendirilmesi ve ağırlıklarının ölçümlenmesini sağlayan Çok Kriterli Karar Verme araçlarıdır [34]. AHP ve ANP'de ölçüm için her soruna ilişkin amaç, kriterler, alt kriterler ve alternatiflerden oluşan bir hiyerarşi ya da ağ oluşturulur. AHP'de alternatifler kriterleri, kriterler de amacı etkilemektedir. Kriterlerin alternatifleri etkilemediği, kriterlerin ve seçeneklerin kendi içlerinde birbirinden bağımsız oldukları varsayılmaktadır [33]. ANP ise bağımlılık ve geri beslemeleri de barındırır ve daha hassas bir ölçüme olanak tanır [35].

$\mathrm{Bu}$ çalışmada oluşturulan proje karmaşıklığ ölçümleme çerçevesi, bünyesinde bağımlı faktörleri barındırdığından, ölçüm yöntemi olarak ANP yöntemi seçilmiştir.

\subsection{Analitik Ă̆ Süreci (ANP)}

Karmaşık yapılı süreçlerde yer alan olaylar ve elemanlar, çok sayıda değişkenden etkilenmektedir. Süreçteki karmaşıklığın anlaşılması için onu oluşturan faktörlerin belirlenmesi ve bir araya getirilmesi gerekmektedir. Faktörler doğru bir şekilde tanımlandıktan sonra çözüme yönelik oluşturulan alternatifler içinden doğru bir seçim yapılması, süreci karmaşıklaştıran nitel ve nicel tüm faktörleri göz önünde bulunduran bir Çok Kriterli Karar Verme Yönteminin kullanılması ile mümkün olacaktır. Herhangi bir araştırmada çalışmanın amacı, bu amaca etki eden faktörler ve çözüm alternatiflerinin hiyerarşik bir düzende yer aldığı AHP'de, alternatifler faktörleri, faktörler de amac1 etkilerken, faktörlerin alternatifleri etkilemediği varsayılır [33]. $\mathrm{Bu}$ yaklaşıma göre faktörler ve alternatifler birbirinden bağımsızdır. Ancak ANP, tek yönlü ilişkilerle sınırlı kalmayıp karmaşık ilişkileri ve faktörlerin ve alternatiflerin bağımlılığını de dikkate alarak daha doğru tahminler ile karar vermeye olanak sağlar. AHP gibi ikili karşılaştırmalara dayanan ANP, amaç, amacı etkileyen faktörler ve çözüm alternatiflerini bir ağ şeklinde ortaya koyarak, doğrudan ilişkilendirilmemiş bileşenler arasındaki dolaylı ilişkileri ve geri beslemeleri de göz önünde bulundurmaya firsat tanır [34]. Amaç, faktörler ve alternatifler ayrı kümeler içerisinde gösterilir.

ANP dört temel adımdan oluşmaktadır: (i) model kurulması ve problemin yapılandırılması, (ii) ikili karşılaştırma matrisi ve öncelik vektörleri, (iii) süpermatris oluşturma ve (iv) en iyi alternatifin seçilmesi.

\subsubsection{Model Kurulumu ve Problem Yapılandırması}

Model kurulması ve problem yapılandırması adımı karar probleminin tanımlanması ve bağımlılıkların tespit edilmesi süreçlerini barındırır. Problem açık bir şekilde ifade edilmeli ve ağ gibi rasyonel bir sistemle ayrıştırılmalıdır [36]. Kriterler ve alt kriterler arasındaki tek yönlü ve karşılıklı tüm ilişskiler ortaya konmalıdır.

\subsubsection{Ikili Karşılaştırma Matrisi ve Öncelik Vektörleri} İkili karşılaştırma matrisleri, uzmanlardan toplanan verilerle oluşturulur. Karar vericilerden, bir kerede iki elemanı (kriter ya da alt kriter) kendi üst düzey kriterlerine nasıl katkıda bulundukları açısından karşılaştırılacağı bir dizi ikili karşılaştırmaya yanıt vermeleri istenir. Göreceli önem değerleri, 1 ile 9 arasında bir ölçekle belirlenir. 1 puan, karşılaştırılan iki elemanın üst düzey kritere göre eşit öneme sahip olduğu anlamına gelirken, 9 puan, karşılaştırılan iki elemandan birinin diğerine göre aşırı öneme sahip olduğunu gösterir.

İkili karşılaştırma matrisleri oluşturulurken kümeler arası, aynı küme içlerinde yer alan elemanlar arası ve tüm elemanlar ile alternatifler arası karşılaştırmalardan yararlanılır. İkili karşılaştırmalar ile elde edilen öncelik vektörleri, söz konusu elemanların göreceli önem değerlerini tahmin etmek için kullanılır.

\subsubsection{Süpermatris Oluşturma}

Birbirine bağımlı etkilere sahip bir sistemde global öncelikleri elde etmek için, bir önceki adımda elde edilen yerel öncelik vektörleri, 'süpermatris' olarak adlandırılan bir matrisin sütunlarına girilir. Süpermatris, aslında her matris segmentinin, bir sistemde var olan iki düğüm (bileşenler veya kümeler) arasındaki ilişkiyi temsil ettiği, bölümlenmiş bir matristir. Süpermatriste yer alan değerler iki bileşenin birbirine etkisini ifade ederken, sıfir değeri iki bileşenin birbirine etkisi olmadığı anlamına gelmektedir. Ağırlıklı süpermatrisin elde edilmesi için süpermatriste yer alan her sütunun toplamı bir olacak şekilde dönüştürülmesi gerekir. Bu dönüşüm işlemi sonucunda ağırlıklı süpermatris elde edilir. Sistemde yer alan bileşenlerin birbirlerine olan uzun dönemli etkilerini elde etmek üzere, ağırlıklı süpermatrisin $(2 k+1)$. üssü alınır. Burada $k$ keyfi olarak belirlenen büyük bir sayıdır ve oluşan bu yeni matris, 'limit supermatris' olarak adlandırılır. Limit süpermatris bütün sütunları aynı olan bir matristir. Bu matriste yer alana bloklar normalize edilerek, her bir elemanın öncelikleri belirlenir.

\subsubsection{En İyi Alternatifin Seçilmesi}

ANP'ye göre en yüksek öncelik seviyesine sahip olduğu belirlenen kriterler, çalışma için anlamlı olanlardır. Yapılan çalışmada amaç alternatiflerden birini seçmekse yüksek önceliğe sahip alternatif seçilebilir veya yapılan çalışmada amaç bir konu ile ilgili en kritik faktörü belirlemekse, bu adımda en yüksek öncelik seviyesine sahip faktör en önemli faktör olarak atanabilir.

\subsection{Uygulama}

Çalışmada gerçekleştirilen uygulama kapsamında dijital bankacılık projelerinde proje karmaşıklığının ölçümlenmesi amaçlanmıştır. Bu doğrultuda, literatür araştırmalarında yer alan çalışmalar incelenerek elde edilen boyutların yeni bir bakış açısıyla derlenmesi 
sonucu oluşturulan model baz alınarak, uzman görüşlerinden elde edilen veriler ile dijital bankacılık projelerinde karmaşıklığı yaratan ve/veya etkileyen en kritik faktörler belirlenmeye çalışılmıştır. Ayrıca bu çalışmada, seçilen iki proje değerlendirilmiş ve projelerin karmaşıklık düzeyleri ile proje bazında karmaşıklık yaratan faktörler belirlenmiştir. Çalışma, hangi projenin daha karmaşık olduğunu ortaya çıkarmaya da firsat tanımıştır.

Çalışmada ele alınan projelerden birincisi "Müşteri Sadakat Projesi"dir. Proje, bankanın pos cihazlarına sahip üye işyerlerinin poslarından gerçekleşmiş dataların baz alınması yoluyla üye işyerlerine kendi datalarından derlenmiş raporlar üreterek muhasebe süreçlerini kolaylaştırmak, üye işyerlerinin bu raporlara göre kendi kampanyalarını yaratmasına imkan tanımak ve ihtiyaçları olan birçok konuda hızlı ve kolay bir şekilde aksiyon alabilmelerini sağlamak amacıyla bir web platformu oluşturmayı hedeflemiştir. Projede şirket kadrosunda çalışan toplamda 9 iş analisti ve yazılım geliştirme mühendisi aktif olarak yer almış, bunun dışında dış kaynak olarak ilave 4 yazılımcı görevlendirilmiştir. Şirket bünyesinde bir analiz ve bir yazılım yöneticisi de yönetim faaliyetlerini üstlenmiştir. Proje için şirket kadrosunda çalışanların harcadığ1 efor toplam 12.691 adam*saat'tir. Projenin önyüz tasarımları için banka dışı bir firmadan destek alınmıştır. Farklı bir firma ile çalışılması ve müşteri için doğrudan bir çıktı oluşturulması bakımından geniş bir kitleyi kapsamında tutmuştur.

Çalışmada ele alınan diğer proje ise "Proaktif Limit Artırım Projesi"dir. Proje, banka risk ekiplerinin üye işyerlerinden geçen ciroları kontrol altında tutmak amaciyla oluşturduğu işlem limitlerinin uygun şartlarda proaktif bir şekilde arttırılmasını amaçlamaktadır. $\mathrm{Bu}$ sayede hem müşteri memnuniyetini artırmak hem de riskli bir durum olmamasına rağmen bankadan geçen cironun engellenmesi durumunu ortadan kaldırmak hedeflenmiştir. Projede iş analisti ve yazılım geliştirme uzmanlarından oluşan 11 kişilik bir ekip aktif olarak görev almıştır. Proje için toplamda 19.707 adam*saat'lik efor harcanmıştır. Şirket bünyesinde bir analiz ve bir yazılım yöneticisi de yönetim faaliyetlerini üstlenmiştir.

\subsubsection{Veri Toplama}

Veri toplama için Türkiye'nin en büyük sermayeli ilk 3 bankasından birinin teknoloji merkezinde gerçekleştirilen "Müşteri Sadakat Projesi" ve "Proaktif Limit Artırım Projesi” baz alınmıştır. Belirlenen karmaşıklık faktörlerini kıyaslaması için iki farklı uzmanın görüşüne başvurulmuştur. Uzmanlardan biri, bahsedilen her iki projede de aktif görev almış 'İş Geliştirme Yetkili Uzmanı' unvanına sahip bir iş analisti, diğeri ise her iki projenin proje yöneticiliğini yapmış, süreçleri yakından takip eden bir 'Proje Yöneticisi'dir. Belirlenen her karmaşıklık faktörü için uzman görüşü alınmadan önce; çalışmanın amacı, proje karmaşıklığının neden ölçümlendiği, ölçümün nasıl yapılacağı, karmaşıklığın tanımı, boyutları, alt boyutları ve her bir alt boyutun ilişkilendirildiği kavramlara ilişkin örnekler paylaşılmış ve uzmanlardan beklentinin ne olduğu açıklanmıştır. Bu yöntemle, ilgili kriterlerin karmaşıklık seviyesinin uzmanlar tarafindan kolaylıkla tahmin edilebilmesi sağlanmaya çalışılmıştır. Süreç; şirket içinde yer alan bir dinlenme alanında, karşılaştırılacak faktörler bilgisayardan uzmanlara gösterilerek ve gerekli yerlerde ek açıklamalar yapılarak, 90'ar dakika süren iki farklı oturumda gerçekleştirilmiştir. Her oturum iki uzmanla aynı anda gerçekleştirilmiş ve uzmanlardan fikir birliğine varmaları beklenmiştir. Birinci oturum proje karmaşıklığı açısından tüm boyutların ve alt boyutların değerlendirilmesi ve tüm boyutlar ve alt boyutlar açısından birinci ve ikinci projenin karşılaştırılması ile ilgili soruları kapsamaktadır. Örnek bazı sorular şu şekildedir:

- "Proje Karmaşıklığı" açısından "Operasyonel" mi yoksa "Yönetsel" faktörler mi daha fazla etkilidir, ne kadar?

- "Proje Karmaşıklığı" açısından "Operasyonel İlişkiler ve Etkileşim” mi yoksa "Operasyonel Yenilik, Değişkenlik ve Belirsizlik” mi daha fazla etkilidir, ne kadar?

- "Operasyonel İlişkiler ve Etkileşim” açısından "Proje-1" mi yoksa "Proje-2" mi daha karmaşıktır, ne kadar?

İkinci oturumda ise her bir faktör altında bulunan alt boyutlardan ilişkili olanların (geri besleme) karşılaştırması ve her bir alt boyutun ilişkili olduğu diğer alt boyutlar ile karşılaştırması yapılmıştır. Örnek bazı sorular şu şekildedir:

- Projelerde "Operasyonel Çeşitlilik ve Büyüklük"e etkisi bakımından "Yönetsel Çeşitlilik ve Büyüklük" mü yoksa "Yönetsel İlişkiler ve Etkileşim" mi daha önemlidir, ne kadar?

- Projelerde “Operasyonel Çeşitlilik ve Büyüklük”e etkisi bakımından Operasyonel İlişkiler ve Etkileşim” mi yoksa “Operasyonel Yenilik, Değişkenlik ve Belirsizlik” mi daha önemlidir, ne kadar?

Yöntem, literatüre dayanılarak belirlenen karmaşıklık faktörleri değerlendirilirken, uzmanlar tarafindan herhangi bir faktöre itiraz edilebilir ya da yeni bir faktör için öneride bulunulabilir olması sebebiyle güven sağlamaktadır. Ancak veri toplama süreci boyunca bu konuda herhangi bir talep gelmemiştir.

\subsubsection{Veri Analizi}

Oluşturulan çerçevede yer alan temel boyutlar, alt boyutlar ve kurulan ilişkilere göre ikili karşılaştırmalar yapılarak toplanan veri, projeleri karmaşıklaştıran faktörlerin kıyaslanması ve karmaşıklık seviyelerinin belirlenmesi için "Super Decisions Software" adlı program kullanılarak değerlendirilmiştir [37]. $\mathrm{Bu}$ kapsamda "Proje karmaşıklığının ölçümlenmesi" 
şeklinde konumlanan hedef, karmaşıklığa sebep olduğu düşünülen boyutlar, bu boyutlara ait alt boyutlar ve alternatifler programa girilmiştir. Her grupta ifade edilen boyut ve alt boyutlar için uygulama sırasında kullanılmak üzere açıklama bölümleri de programa eklenmiştir. Oluşturulan modelin ekran görüntüsü Şekil 5 'te verilmiştir.

Kurulan modelde amacın tüm alt boyutlardan etkilendiği kabul edildiğinden, amaç ile tüm alt boyutlar ilişkilendirilmiştir. Karmaşıklık bakımından kıyaslanması hedeflenen iki proje de tüm alt boyutlar açısından kıyaslanacaktır; dolayısıyla, alt boyutların tamamı alternatif iki proje ile ilişkilendirilmiştir. Son olarak, her alt boyutu etkileyeceği düşünülen diğer alt boyutlar, literatür araştırması sonucu edinilen bilgi ve tecrübelere dayalı olarak belirlenmiştir.

Faktörler ve ilișkilerin tanımlanması sonucu oluşturulan nihai modele göre, 1 ile 9 puan aralığında (1 puan, karşılaştırılan iki elemanın üst düzey kritere göre eşit öneme sahip olması, 9 puan, karşılaştırılan iki elemandan birinin diğerine göre aşırı öneme sahip olması) yapılan kıyaslamalar ile toplanan veriler programa girilmiştir. Her bir karşılaştırma için programda ilgili karşılaştırma matrislerine girilen cevaplara ilişkin tutarsızlık değerleri, kabul edilebilir eşik değer olan \%10 değerinin altında çıkmıştır.

\subsubsection{Bulgular ve Değerlendirme}

Programın çalıştırılması ile elde edilmiş sonuçlar Tablo 3 'te özetlenmiştir. Tabloda karmaşıklığı oluşturan her bir alt boyutun, içinde bulunduğu temel boyut (küme) içerisindeki önem değerleri ve global önem değerleri görülmektedir. 'Operasyonel karmaşıklık' kümesindeki en önemli alt boyut \%30,44'lük önem değeri ile 'operasyonel yenilik, değişkenlik ve belirsizlik' olarak belirlenmiştir. Bu boyut operasyonel işin detaylarına yönelik belirsizlikleri, kalite, zaman gibi operasyonel hedefler ve yöntem/süreçlere ilişkin belirsizlikleri; ayrıca projedeki yeni/tanınmayan ögeleri ifade etmektedir. 'Yönetsel karmaşılık' kümesindeki en önemli alt boyut \%31,16'l1k önem değeri ile 'yönetsel risk'tir. Yönetsel riskler gerçekleşmesi durumunda projenin devam etmesini aksatacak, çalışanlarla ilgili riskleri ifade etmektedir. 'Organizasyonel karmaşıklık' kümesindeki en önemli alt boyut \%38,57'lik önem değeri ile 'organizasyonel yenilik, değişkenlik ve belirsizlik' olarak belirlenmiştir. Organizasyonel belirsizlik vizyon, misyon ve organizasyonel yapının yanı sıra performans göstergeleri, süreçler ve standartlardaki belirsizlikleri ifade etmektedir. Organizasyonel değişkenlik organizasyon genelinde kullanilan teknolojilerin, finansal kaynakların, vs. süreç içindeki değişiminini ifade etmektedir. Yeni organizasyonel yap1 da bu boyut altında ele alınmaktadır. 'Çevresel karmaşıklık' kümesindeki en önemli alt boyut ise \%22,03'lük önem değeri ile 'çevresel risk' olarak saptanmıştır. Çevresel riskler gerçekleşmesi durumunda projenin devam etmesini aksatacak olan paydaşlarla ilgili, dişsal kaynaklarla ilgili ve genel çevrede meydana gelebilecek riskleri ifade etmektedir.

Tüm boyutlar için belirlenen global önem seviyelerine bakıldığında \%6,0 ile 'çevresel risk' en önemli; \%5,9 ile 'organizasyonel yenilik, değişkenlik ve belirsizlik' ikinci en önemli ve \%5,3 ile 'çevresel çeşitlilik ve büyüklük' üçüncü en önemli alt boyut olarak ortaya çıkmıştır. Bu sonuçlara göre, alt boyutlara odaklanan bir proje yöneticisi, projenin doğasında var olan veya işleyişi sırasında oluşabilecek karmaşıklığı yönetmek için çevresel risklere yönelik risk yönetim metodolojilerinden faydalanarak bir strateji oluşturmalı ve çevresel riskleri ortadan kaldırmaya ya da risklerin olasılık ve etkilerini azaltmaya odaklanmalıdır. 'Organizasyonel yenilik, değişkenlik ve belirsizlik' boyutu ve paydaşların ve projenin görev çevresinde yer alan dış bağımlılıkların (kaynaklar, teknolojiler, vb.) sayısı ve çeşitliliği ile genel çevrede var olan çeşitliliği ifade eden 'çevresel çeşitlilik ve büyüklük' boyutu da proje yönetim stratejileri belirlenirken karmaşıklık ile başa çıkmayı sağlayacak adımların planlanması için öncelikli olarak düşünülmesi gereken faktörlerdendir.

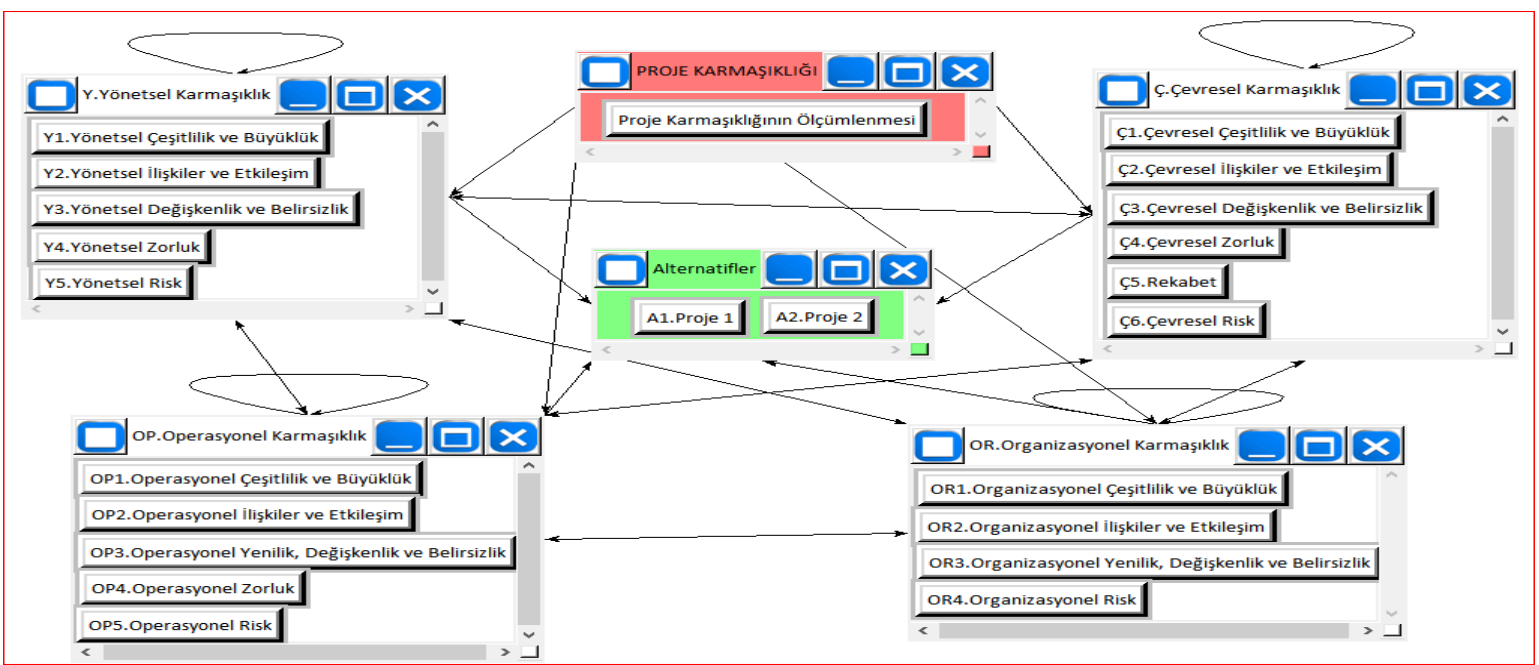

Şekil 5. Proje karmaşıklık ölçüm modeli ekran görüntüsü 
Global önem seviyelerine bakıldığında sirasıyla 'çevresel değişkenlik ve belirsizlik', 'organizasyonel risk', 'operasyonel yenilik, değişkenlik ve belirsizlik', 'çevresel ilişkiler ve etkileşim', 'operasyonel çeşitlilik ve büyüklük', 'organizasyonel ilişkiler ve etkileşim', 'yönetsel çeşitlilik ve büyüklük' takip eden diğer en önemli alt boyutlar olarak dikkat çekmektedir. Operasyonel karmaşıklık boyutu ve bu boyuta ait alt boyutlar projede direkt olarak yapılan işlerle ilgili; yönetsel karmaşıklık boyutu ve bu boyuta ait alt boyutlar ise projede direkt olarak çalışan kişilerle ilgili değerlendirilmektedir. Organizasyonel yenilik, değişkenlik, belirsizlik ve riskler projenin gerçekleştiği organizasyonun yapısı ile ilgili faktörlerle; çevresel çeşitlilik, büyüklük, ilişkiler, etkileşim, değişkenlik, belirsizlik ve riskler ise projenin etkileşim içinde olduğu görev çevresi ve projenin gerçekleştiği organizasyonun içinde bulunduğu genel çevre ile ilişkilidir.

Her bir temel boyutun proje karmaşıklığına etkileri ise Tablo 4'te özetlenmiştir. Tablo 4'te verilen önem değerlerine göre karmaşıklığı etkileyen en önemli faktör \%57,88'lik önem değeri ile 'yönetsel karmaşıklık' olurken, bunu \%28,88'lik önem değeri ile 'çevresel karmaşıklık' izlemektedir. Belirlenen boyutlardan karmaşıklığa göreceli olarak en az etki eden boyut ise \%3,98 önem değerine sahip olan 'organizasyonel boyut' olarak saptanmıştır. Dolayısıyla bir projeyi karmaşıklaştıran en önemli faktörlerin projenin insan boyutu ile ilgili faktörler olduğu söylenebilir. Projede çalışan bireylerin sayısı ve dil, kültür, beklenti, ilgili alanı, vb. çeşitliliği; projedeki uzmanlıklar ve dahil olan disiplinler; zayıf tanımlanmış, gerektirdiği uzmanlık seviyesi belirsiz olan rollerin varlığından kaynaklanan belirsizlikler; bireylerin takvimleri, planlamaları ve görevleri arasındaki bağımlılık ve etkileşimler; takım üyelerinin değişmesi, uzmanlık ihtiyaçlarındaki değişimler, vb. değişkenlikler bu kapsamda yönetilmesi gereken başlıca konulardır. Çevresel karmaşıklık ise paydaşların ve dış bağımlılıkların sayısı, çeşitliliği; paydaşlar arası iletişim ve bilgi paylaşımı ve organizasyon dışı teknolojik, yasal, sosyal ve çevresel olayların projeye etkilerini ifade eder. Aniden ortaya çıkan yeni teknolojilerden hava koşullarına, rakiplerin davranışlarına kadar çevrede gerçekleşen birçok durumun projeye etkisi olabilir. Dolayısıyla, çevresel faktörlerin de karmaşıklık yönetiminde ön planda olması gerekmektedir. Proje karmaşıklığına en az etki eden boyut olarak belirlenen 'organizasyonel boyut' ise dikey ve yatay organizasyonel yap1, organizasyon içindeki bağımlılıklar, iletişim ve ilişki düzeyi, vizyon ve misyon, standartlar, süreçler ve bunlardan kaynaklanan değişkenlik ve belirsizlikleri kapsamaktadır. 'Organizasyonel boyut', proje karmaşıklığı konusunda en az etkiye sahip görünse de başarılı bir proje yönetimi için yine de dikkate alınması gerekmektedir.

Tablo 3. Proje karmaşıklık alt boyutlarının önem değerleri

\begin{tabular}{|c|c|c|c|}
\hline $\begin{array}{l}\text { Karmaşıklık } \\
\text { Boyutları }\end{array}$ & Alt Boyutlar & $\begin{array}{c}\text { Boyutlar Bazında Önem } \\
\text { Değerleri (\%)* }\end{array}$ & $\begin{array}{l}\text { Global Önem } \\
\text { Değerleri (\%) }\end{array}$ \\
\hline \multirow{6}{*}{$\begin{array}{l}\text { Operasyonel } \\
\text { Karmaşıklık }\end{array}$} & Operasyonel Çeşitlilik ve Büyüklük & 28,47 & 4,4 \\
\hline & Operasyonel İlişkiler ve Etkileşim & 10,29 & 1,6 \\
\hline & \multirow{2}{*}{$\begin{array}{l}\text { Operasyonel Yenilik, Değişkenlik ve } \\
\text { Belirsizlik }^{* * *}\end{array}$ ve } & $3044^{* *}$ & 47 \\
\hline & & 30,44 & $4, /$ \\
\hline & Operasyonel Zorluk & 14,16 & 2,2 \\
\hline & Operasyonel Risk & 16,64 & 2,5 \\
\hline \multirow{5}{*}{ Yönetsel Karmaşıklık } & Yönetsel Çeşitlilik ve Büyüklük & 13,49 & 4,2 \\
\hline & Yönetsel Îliskiler ve Etkilesim & 7,04 & 2,7 \\
\hline & Yönetsel Yenilik, Değişkenlik ve Belirsizlik & 28,15 & $5,9^{* * *}$ \\
\hline & Yönetsel Zorluk & 20,17 & 2,5 \\
\hline & Yönetsel Risk ${ }^{* *}$ & $31,16^{* *}$ & 2,1 \\
\hline \multirow{4}{*}{$\begin{array}{l}\text { Organizasyonel } \\
\text { Karmaşıklık }\end{array}$} & Organizasyonel Çeşitlilik ve Büyüklük & 27,46 & 1,1 \\
\hline & Organizasyonel İlişkiler ve Etkileşim & 17,52 & 4,3 \\
\hline & $\begin{array}{l}\text { Organizasyonel Yenilik, Değişkenlik } \\
\text { Belirsizlik }\end{array}$ & $38,57^{* *}$ & 3,1 \\
\hline & Organizasyonel Risk & 16,46 & 4,8 \\
\hline \multirow{6}{*}{ Çevresel Karmaşıklık } & Çevresel Çeşitlilik ve Büyüklük & 19,44 & $5,3^{* * *}$ \\
\hline & Çevresel İlişkiler ve Etkileşim & 17,18 & 4,6 \\
\hline & Çevresel Değişkenlik ve Belirsizlik & 18,06 & 4,9 \\
\hline & Çevresel Zorluk & 10,28 & 2,8 \\
\hline & Rekabet & 13,02 & 3,5 \\
\hline & Çevresel Risk $^{* *}$ & $22,03^{* *}$ & $6,0^{* * * *}$ \\
\hline & önem değerleri & \\
\hline & boyutlar & \\
\hline & klık alt boyutları birlikte değerlendirildiğinde & lem değeri en yüksek & byutlar \\
\hline
\end{tabular}


Tablo 4. Proje karmaşıklık boyutlarının önem değerleri

\begin{tabular}{lc}
\hline Karmaşıklık Boyutları & Önem Değerleri (\%) \\
\hline Operasyonel Karmaşıklık & 9,26 \\
Yönetsel Karmaşıklık & $57,88^{*}$ \\
Organizasyonel Karmaşıklık & 3,98 \\
Çevresel Karmaşıklık & 28,88 \\
\hline
\end{tabular}

* $\quad$ : Önem değeri en yüksek karmaşıklık boyutu

Çalışma kapsamında proje karmaşıklığının ölçümlenmesine yönelik oluşturulan çerçevede yer alan tüm faktörler ve alt faktörlerin, uygulamada kullanılmak üzere belirlenen projelere göre değerlendirilmesi sonucunda Tablo 5'te görüldüğü gibi "Müşteri Sadakat Projesi”nin (Proje 1) "Proaktif Limit Artırım Projesi”nden (Proje 2) daha karmaşık olduğu sonucuna ulaşı1mıştır.

Tablo 5. Alternatif projelerin karmaşıklık seviyeleri

\begin{tabular}{lc}
\hline \multicolumn{1}{c}{ Alternatif Projeler } & Karmaşıklık Seviyeleri (\%) \\
\hline $\begin{array}{l}\text { Müşteri Sadakat Projesi } \\
\text { (Proje 1) }\end{array}$ & 56,46 \\
$\begin{array}{l}\text { Proaktif Limit Artırım } \\
\text { Projesi (Proje 2) }\end{array}$ & 43,54 \\
\hline
\end{tabular}

Belirlenen iki farklı dijital bankacılık projesinin karmaşıklığının ölçümlenmesinde kullanılan çerçeve, sektör ve proje tipinden bağımsız, herhangi iki veya daha fazla projenin karmaşıklık açısından karşılaştırılması için rahatlıkla kullanılabilir. Elde edilen sonuçlar, projelerin sadece karmaşıklıkları bakımından değerlendirilmesi ile yapılmış bir önceliklendirme ortaya koymaktadır. Proje seçiminde karmaşıklık, dikkate alınması gereken faktörlerden sadece birisidir. $\mathrm{Bu}$ bakımdan seçim ile ilgili karar vermeden önce maliyet ve getiri hesabının yanında karmaşıklık dışındaki proje başarısını etkileyen diğer tüm faktörler de göz önünde bulundurulmalıdır. Gerçekleştirilen bu uygulama, alternatif projeler arasından seçim yapmak için ihtiyaç duyulan bilgiyi (karmaşıklık düzeyleri ile ilgili) sağlamasının yanı sıra, çalışmanın amacı doğrultusunda proje karmaşıklığı değerlendirilirken kullanılabilecek karmaşıklık faktörlerinin önem değerlerini de ortaya koymaktadır. $\mathrm{Bu}$ sonuçlar, projelerde karmaşıklık yönetimi için ağırlık verilmesi gereken boyutların ne olduğunu göstererek uygun yönetim stratejisi ile daha etkin bir biçimde yönetilmesine olanak tanıyacak ve proje başarısının artmasına katkı sağlayacaktır.

\section{SONUÇ VE ÖNERILLER}

Proje karmaşıklığı, proje hedeflerine ulaşılmasını zorlaştırdığından, proje yönetimi için kritik bir faktörlerden bir tanesidir. Karmaşıklığı anlamak, hem akademik çalışmalar, hem de pratikte projelerin karmaşıklığını yönetmek durumunda olan proje yöneticileri için büyük bir öneme sahiptir. Karmaşıklığ analiz etmek için araçlara sahip olmak, karmaşıklığın daha iyi anlaşılmasını sağlayacak ve proje yöneticilerini karmaşıklığın nasıl yönetileceğine dair güzel bir başlangıç noktasına getirecektir. Bu tür bir araç proje yöneticilerine projenin durumunu formüle etme, stratejik seçimler yapma, yönetim sürecini seçme ve uygulama süresince kararlar alma konusunda yardımcı olacaktır. Tüm bunlar, yönetsel kapasitenin çok daha etkili kullanılmasını sağlayacak ve yönetsel yetkinliklerin de gelişmesine katkıda bulunacaktır.

Proje karmaşıklığı farklı göstergeler kullanılarak ölçümlenebilmektedir. Yapılan çalışmalarda kullanılan istatistiksel analizler en önemli ve proje karmaşıklığını en iyi yansıtan faktörleri belirlemeyi amaçlamaktadır. Başka bir deyişle, daha az karmaşık projeler ile daha karmaşık projeler arasında istatistiksel olarak fark yaratan göstergeler, proje karmaşıklığını tanımlamada etkili olan faktörleri anlamaya yardımcı olmaktadır.

Algılanan karmaşıklıkta geçmiş deneyimler önemli bir role sahip olduğundan, bir projenin karmaşıklığını değerlendirmenin doğasında sübjektiflik bulunmaktadır [13]. Yetkinlik ve deneyimlerdeki farklılıklar sebebiyle, insanların bir projeyi aynı çerçeveyi kullanarak değerlendirdiği durumlarda bile karmaşıklığa ilişkin farklı sonuçlar çıkabilmektedir. Bu sebeple proje karmaşıklığına dair oluşturulan çerçevelerde aslında temel amaç proje karmaşıklığını daha iyi anlamak ve proje karmaşıklığına ilişkin bir iz bulabilmektir. Karmaşıklık alanlarının bilinmesi, bu alanların yönetimi sırasında daha dikkatli olunmasını sağlayacaktır.

Projenin erken aşamalarında karmaşıklığın ölçümlenmesi projenin daha iyi anlaşılmasını sağlar ve bu sayede projelerin başarılı bir şekilde yönetilmesine ve karmaşıklığın yaratacağı risklerin azaltılmasına olanak tanır. Bir projenin başlangıç aşamasında yapılan değerlendirmeler, projenin beklenen karmaşıklığının belirlenmesi ve özel tedbirlerin alınmasını sağlayabilir. Örneğin teknik karmaşıklığının yüksek olduğu belirlenen bir proje, çevresel karmaşıklığı yüksek olan bir projeye göre farklı özelliklere sahip bir proje yöneticisi gerektirebilir. Remington ve Pollack (2016) çok fazla sayıda karmaşık projenin, söz konusu projeler kontrol altında tutulamayacak ve yardım edilemeyecek noktaya gelene kadar karmaşık oldukları belirlenmediği için başarısız olduğunu belirtmiştir [15]. Öte yandan, sadece başlangıç aşamasında proje karmaşıklığının ölçümlenmesi de yetersiz kalabilir. Proje karmaşıklığı proje yaşam döngüsü boyunca değiştiğinden, proje karmaşıklığının dinamikliğini anlamak için, oluşturulan çerçevenin projenin çeşitli aşamalarında tekrar tekrar düşünülmesi ve değerlendirilmesi gerekmektedir.

Karmaşıklığın ölçümlenmesi stratejik seçimler, süreç seçimleri, geliştirme, kaynak ayırma, iş vakaları, yönetsel kapasite ve yetkinliklerin değerlendirilmesi gibi proje yönetimi ile ilişkili birçok konuda önemli derecede destek sağlayabilir. Proje karmaşıklığının 
ölçümlenmesi sadece proje yönetimine destek vermekle kalmayıp herhangi bir organizasyonun portföyünde yer alan bir projenin seçilmesi veya projelerin önceliklendirilmesi ya da projelerde var olan veya doğabilecek çeşitli problemlerin tanımlanması için de kullanılabilir.

Bu çalışma kapsamında geliştirilen proje karmaşıklığı ölçüm modeli ile dijital bankacılık projelerinde proje karmaşıklığının ölçümlenmesine yönelik bir uygulama yapılmış ve uygulama sonucunda dijital bankacılık projelerinde karmaşıklık yaratan en önemli faktörler yönetsel ve çevresel faktörler olarak saptanmıştır. Yönetsel faktörler, projenin insan ile ilgili boyutundan beslenmektedir. Dolayısıyla, proje ekibindeki kişilerin sayısı, uzmanlıkları, farklılıkları, iletişimi ve ilişkilerinden; zayıf tanımlanmış rollere, uzmanlık ihtiyaçlarındaki değişime kadar geniş bir çerçevede değerlendirilebilecek faktörlerin projeleri karmaşıklaştırmadaki etkisi büyüktür. Çevresel karmaşıklık ise projenin ilişkili olduğu görev çevresi ve genel çevredeki faktörleri kapsar. Projenin paydaşları, tedarikçileri, müşterileri ve partnerleri ile ilgili faktörler, projenin dış bağımlılıkları ile ilgili belirsizlik ve riskler ve projenin genel çevresinde meydana gelmiş ancak projeye etki edebilecek yenilik ve değişiklikler proje karmaşıklık yönetimi sürecinde mutlaka dikkate alınması gereken konulardır. Bununla birlikte, literatürde yer alan hemen hemen tüm modeller gibi bu çalışma ile ortaya konan modelin de sektörden bağımsız olarak her tip projenin karmaşıklığının ölçümlenmesinde kullanılması uygundur. Literatürde yapılan çalışmalarda herhangi bir faktörün daha az karmaşık olduğunu söyleyen bireylerin, o faktörü yaratan duruma benzer bir durumla daha önce karşılaştığ 1 ve ilgili durumu nasıl tasarlayacağını bildiği vakalara rastlanmış; hatta bu durumun diğer uzmanlara aktarılmasının, diğerlerinin de fikirlerini değiştirmelerine neden olduğu gözlemlenmiştir. Bu durum, karmaşı projelerin daha verimli yönetilmesinde iletişimin önemini ortaya koymaktadır. $\mathrm{Bu}$ çalışmada gerçekleştirilen uygulamada toplanan veri de uzman görüşlerine bağlı sübjektif veri olduğundan, yakın sonuçlar beklenmekle birlikte, farklı uygulayıcılarla yapılan çalışmaların farklı sonuç vermesi normal karşılanmaktadır.

\section{KAYNAKLAR}

[1] PMI Standards Committee. (2004). A Guide to the project management body of knowledge: (PMBOK Guide). Upper Darby, Pennsylvania, Project Management Institute.

[2] Lu, Y., Luo, L., Wang, H., Le, Y., \& Shi, Q. (2015). Measurement model of project complexity for largescale projects from task and organization perspective. International Journal of Project Management, 33(3), 610-622.

[3] Wood, H., \& Ashton, P. (2015). The factors of project complexity. University of Brighton: Retrieved from http://eprints.brighton.ac.uk/id/eprint/14062.
[4] Dao, B., Kermanshachi, S., Shane, J., Anderson, S., \& Hare, E. (2016b). Identifying and measuring project complexity. Procedia Engineering, 145, 476-482.

[5] Baccarini, D. (1996). The concept of project complexity - A review. International Journal of Project Management, 14(4), 201-204.

[6] Geraldi, J. \& Adlbrecht, G. (2007), On faith, fact and interaction in projects. Project Management Journal, 38(1), 32-43.

[7] Vidal, L. A., Marle, F., \& Bacquet, J. (2011). Measuring project complexity using the Analytic Hierarchy Process. International Journal of Project Management, 29(6), 718-727.

[8] Cicmil, S., Cooke-Davis, T., Crawford, L., \& Richardson, K. (2009). Exploring the complexity of projects: Implications of complexity theory for project management practice. Newtown Square: Project Management Institute.

[9] Gidado, K. (1996). Project complexity: The focal point of construction production planning. Construction Management and Economics 14(3), 213225.

[10] Williams, T. (1999). The need for new paradigms for complex projects. International Journal of Project Management, 17(5), 269-273.

[11] Lucas, C. (2006). Quantifying Complexity Theory. Retrieved from http://www.calresco.org/lucas/quantify.htm.

[12] Brockmann, C., \& Girmscheid, G. (2007). The inherent complexity of large scale engineering projects. Project Perspectives, 29, 22-26.

[13] Bosch-Rekveldt, M., Jomgkind, Y., Mooi, A., Bakker, H., \& Vercraeck, A. (2011). Grasping project complexity in large engineering projects: The TOE (Technical, Organizational and Environmental) framework. International Journal of Project Management, 29(6), 728-739.

[14] Xia, B., \& Chan, A. P. (2012). Measuring complexity for building projects: A Delphi study. Engineering, Construction and Architectural Management, 19(1), 7-24.

[15] Remington, K., \& Pollack, J. (2016). Tools for complex projects. London: Routledge.

[16] Dao, B., Kermanshachi, S., Shane, J., Anderson, S., \& Hare, E. (2017). Exploring and Assessing Project Complexity. Journal of Construction Engineering and Management, 143(5), 04016126-1,04016126-10.

[17] Qureshi, S.M., \& Kang, C.W. (2015). Analysing the organizational factors of project complexity using structural equation modelling. International Journal of Project Management, 33(1), 165-176.

[18] Maylor, H., Vidgen, R., \& Carver, S. (2008). Managerial complexity in project-based operations: A grounded model and its implications for practice. Project Management Journal, 39 (1_suppl), S15-S26.

[19] Dao, B., Kermanshachi, S., Shane, J., \& Anderson, S. (2016a). Project complexity assessment and management tool. Procedia Engineering, 145, 491-496. [20] Vidal, L. A., \& Marle, F. (2008). Understanding project complexity: Implications on project 
management. Kybernetes, 37(8), 1094-1110.

[21] Zhu, J., \& Mostafavi, A. (2017). Discovering complexity and emergent properties in project systems: A new approach to understanding project performance. International Journal of Project Management, 35(1), 112.

[22] GAPPS. (2007). A Framework for Performance Based Competency Standards for Global Level 1 and 2 Project Managers. Sydney: Global Alliance for Project Performance Standards

[23] Geraldi, J., Maylor, H., \& Williams, T. (2011). Now, let's make it really complex (complicated): A systematic review of the complexities of projects. International Journal of Operations \& Production Management, 31(9), 966-990.

[24] Williams, T. (2005), Assessing and moving from the dominant project management discourse in the light of project overruns. IEEE Transactions on Engineering Management, 52(4), 497-508.

[25] Maylor, H., \& Turner, N. (2017). Understand, reduce, respond: project complexity management theory and practice. International Journal of Operations \& Production Management, 37(8), 1076-1093.

[26] Choudary, K. S. A., Rao, U. V. A., \& Kumar, M. A. (2019). Assessment of Project Complexity: ERP System in Large Scale Process Enterprises. Advance and Innovative Research, 6(2), 49.

[27] Dao, B., Kermanshachi, S., Shane, J., Anderson, S., \& Hare, E. (2017). Exploring and assessing project complexity. Journal of construction engineering and management, 143(5), 4016126.

[28] Kermanshachi, S., Dao, B., Rouhanizadeh, B., Shane, J., \& Anderson, S. (2020). Development of the project complexity assessment and management framework for heavy industrial projects. International Journal of Construction Education and Research, 16(1), 24-42.
[29] Kermanshachi, S., Rouhanizadeh, B., \& Dao, B. (2020). Application of Delphi Method in Identifying, Ranking, and Weighting Project Complexity Indicators for Construction Projects. Journal of Legal Affairs and Dispute Resolution in Engineering and Construction, 12(1), 4519033.

[30] Luo, L., Zhang, L., \& Wu, G. (2020). Bayesian belief network-based project complexity measurement considering causal relationships. Journal of Civil Engineering and Management, 26(2), 200-215.

[31] Ma, L., \& Fu, H. (2020). Exploring the influence of project complexity on the mega construction project success: a qualitative comparative analysis (QCA) method. Engineering, Construction and Architectural Management, EarlyCite, 1-21.

[32] Lebcir, R., \& Choudrie, J. (2011). Impact of project complexity factors on project cycle time: A system dynamics modelling approach. In proceedings of $2^{\text {nd }}$ International Conference on Construction and Project Management, September, 16-18, Singapore, 166-170.

[33] Topçu, Y.İ. (2019). Analitik hiyerarşi ve ağ süreci. Retrieved from www.ilkertopcu.net

[34] Saaty, T.L. (1990). How to Make a Decision: The analytic hierarchy process. European Journal of Operational Research, 48(1), 9-26.

[35] Saaty, T.L. (2001). Decision making with dependence and feedback: The analytic network process - The organization and prioritization of complexity. New York: RWS Pub.

[36] Asan, U., \& Soyer, A. (2009). Identifying strategic management concepts: An analytic network process approach. Computers \& Industrial Engineering, 56(2), 600-615.

[37] Super Decisions [Computer Software]. (2019). Retrieved from https://www.superdecisions.com. 